\title{
I8. Yüzyılda Sarraf Katlleri: “Devlet Malına Halel”in mi, Hizipleşmenin mi Kurbanları?
}

\author{
Ertan Ünlü*
}

\begin{abstract}
Sarraf Executions in the 18 $8^{\text {th }}$ Century: Were They the Victims of "Harming Goverment Property" or "Factionalism"?
\end{abstract}

Abstract - This article is about certain sarrafs who were executed in the $18^{\text {th }}$ century. The main question I examine is whether these sarraf executions were caused by a concern to prevent "harm to the goverment property" or by "factionalism" considering the circumstances of the period. The reason for focusing on $18^{\text {th }}$ century is twofold: 1) The struggle between centeral and peripheral elite to seize the economic surplus was intense at that period. 2) This century was the "golden age" for the sarrafs.

Keywords: Sarrafs, sarraf executions, government property, $18^{\text {th }}$ century, factionalism

\section{Giriş}

Tarihin her dönemi, ister iktidarı ele geçirme amacıyla ister ekonomik artığa el koyma amacıyla olsun, kişiler ya da gruplar arasındaki rekabet, hizipleşme vb. şekillerde adlandırılabilecek çeşitli mücadele örnekleriyle doludur. ${ }^{1}$ Osmanlı Devleti'nde de erken dönemlerden itibaren bu tür mücadele örneklerine rastlamak mümkündür. Özellikle de merkezdeki yönetici elitler ve onların kapı halkı etrafında oluşan siyasi hizipler, makamları elde etmek için isim karalama,

* Ankara Üniversitesi.

1 Ankara Üniversitesi Bilimsel Araştırma Projeleri Koordinatörlüğü tarafından desteklenen "16L0649002" kodlu proje kapsamında hazırlanan bu çalışma, 4-8 Ekim 2016 tarihleri arasında Trabzon'da gerçekleştirilen 22. CIEPO Sempozyumu'nda sözlü bildiri olarak sunulmuştur. 
dedikodu gibi farklı entrika yöntemleriyle sürekli bir çekişme içinde olmuşlardır. ${ }^{2}$ Girdikleri mücadeleler sonucu bazıları nüfuz kazanırken bazıları da gözden düşerek hayatlarını kaybetmeye varan uygulamalara maruz kalmışlardır. ${ }^{3}$ Dolayısıyla 18. yüzyılda katledilen sarrafları konu edindiğimiz bu makale, sarrafların böyle bir mücadeleye kurban gidip gitmediklerini irdelemeyi amaç edinmektedir. ${ }^{4} \mathrm{Bir}$ başka deyişle bu çalışma, dönemin konjonktürü göz önüne alınarak sarrafların

2 Florian Riedler, Osmanlı Imparatorluğu’nda Muhalefet ve Meşruiyet: Siyasi Kültür ve Komplolar, çev. Azize F. Çakır (İstanbul: Picus Yay., 2012), s. 21-23; Carter V. Findley, Osmanlı İmparatorluğủnda Bürokratik Reform Babıâli, 1789-1922, çev. Ercan Ertürk (İstanbul: Tarih Vakfi Yurt Yayınları, 2014), s. 44-45. Bu tür çekişmelere bir örnek olarak, Kanuni Sultan Süleyman, II. Selim ve III. Murad dönemlerinde sadrazamlık yapan Sokullu Mehmed Paşa verilebilir. Mehmed Paşa, III. Murad döneminde sadrazamlık görevini sürdürmeye devam etmekle birlikte, aleyhindeki faaliyetlerin giderek artması nedeniyle, makamını muhafaza etmekte zorlanmaya başlamışır. Rakiplerinin padişaha yaptıkları telkinler sonucunda Mehmed Paşa, kendi yetkisinde olan tayinlerde ve diğer işlerde bile devre dışı bırakılmıştır. Onun en yakın adamları olan Feridun Ahmed Bey nişancılıktan azl edilmiş, kethüdası Hüsrev Ağa ile kapıcıbaşısı Sinan Ağa da yanından uzaklaştırılmıştır. Sokullu Mehmed Paşa ve yaşanılan bu mücadele ile ilgili geniş bilgi için bkz. Erhan Afyoncu, "Sokullu Mehmed Paşa", Türkiye Diyanet Vakfi İlâm Ansiklopedisi (TDV İlâm Ansiklopedisi), 2009, XXXVII, s. 354-357; Şefik Peksevgen, Secrecy, Information Control and Power Building in the Ottoman Empire, 1566-1603, (doktora tezi), Montreal 2004. Başka bir örnek için ayrıca bkz. Elif Özgen, Grand Vizier Koca Sinan Paşa and Factional Politicis in the Court of Murad III (yüksek lisans tezi), İstanbul Bilgi Üniversitesi 2010.

3 Suraiya Faroqhi, "Krizler ve Değişim 1590-1699”, Osmanlı Imparatorluğu’nun Ekonomik ve Sosyal Tarihi (1600-1914), c. II, ed. Halil İnalcık ve Donald Quataert, çev. Ayşe Berktay, Süphan Andıç, Serdar Alper (İstanbul: Eren Yay., 2006), s. 695.

4 Sarraflar hakkında geniş bilgi için bkz. Necibe Sevgen, "Nasıl Sömürüldük?: Sarraflar”, Belgelerle Türk Tarihi Dergisi, 13 (1968), s. 46-59; 14 (1968), s. 66-68; 15 (1968), s. 59-65; 16 (1969), s. 54-61; 17 (1969), s. 62-66; 18 (1969), s. 76-78; 19 (1969), s. 66-67; 20 (1969), s. 69-70; 21 (1969), s. 67-69; 22 (1969), s. 66-71; 23 (1969), s. 74-75; 24 (1969), s. 5460; 25 (1969), s. 73-74; Onnik Jamgoçyan, Les Finances de l'Empire Ottoman et les Financiers de Constantinople (1732-1853) (doktora tezi), Sorbonne 1988; aynı yazar, Osmanl Imparatorluğu'nda Sarraflık: Rumlar, Museviler, Frenkler, Ermeniler (1650-1850), çev. Erol Üyepazarcı (İstanbul: YKY, 2017); Araks Şahiner, The Sarrafs of İstanbul: Financiers of the Empire (yüksek lisans tezi), Boğaziçi Üniversitesi Sosyal Bilimler Enstitüsü, 1995; Yavuz Cezar, "18. ve 19. yüzyılda Osmanlı Devleti'nde Sarraflar”, Gülten Kazgan’a Armağan: Türkiye Ekonomisi, haz. Hilal Akgül ve Fahri Aral (İstanbul: Bilgi Üniversitesi Yay., 2004), s. 179-207; aynı yazar, "The Role of the Sarrafs in the Ottoman Finance and Economy in the Eighteenth and Nineteenth Centuries", Frontiers of the Ottoman Studies, vol. I, ed. Colin Imber ve Keiko Kiyotaki, (London: I. B. Tauris, 2005), s. 61-76; Ali Akyıldız, "Sarraflık: Osmanlı Dönemi”, TDV İslâm Ansiklopedisi, 2009, XXXVI, s. 163-165; Nebi Bozkurt, "Sarraflık", TDV İslâm Ansiklopedisi, 2009, XXXVI, s. 162-163; Nuran Koyuncu, "Osmanlı Devleti'nde Sarrafların Mültezimlere Kefilliği”, İnönü Üniversitesi Hukuk Fakültesi Dergisi, V/1 (2014), s. 295-326; 
sadece "devlet malına halel"den mi katledildikleri, yoksa hizipleşmenin bu katllerde bir rolünün olup olmadığı sorunsalı etrafında şekillenmektedir.

Dönem olarak ise çalışmanın odağında 18. yüzyıl bulunmaktadır. Çünkü bazı araştırmacılar, bu yüzyılın sarrafların "altın çağı" olduğunu vurgulamaktadır. ${ }^{5}$ Ayrıca Oktay Özel, 18. yüzyılın, "Osmanl İmparatorluğu’nda bir yandan merkezi devlet ve onun yüksek görevlileri, diğer yandan her çeşidiyle palazlanan taşra aristokrasisi ve bu ikisi arasinda anahtar rolü oynayan büyük sarraflar ve ticaret burjuvazisi üģgeninde, kurulan ve bozulan ittifaklarla, kızışan ekonomik artığa el koyma mücadelesinin çeşitli tezabürleri olarak okunabileceği ${ }^{\prime \prime}$ i belirtmektedir. ${ }^{6}$

Bilindiği gibi Osmanlı ekonomik ve mali sisteminde sarrafların faaliyetlerine erken dönemlerden itibaren rastlanmaktadır. Çoğunlukla gayrimüslim Osmanlı tebaası Rum, Ermeni ve Yahudilerden oluşan sarraflar, para bozma, değerli madenlerin alım-satımı ve kredi verme gibi görevler üstlenmişlerdir. Başta İstanbul olmak üzere ticaretin yoğun olduğu taşra kentlerinde faaliyet gösteren sarrafların devlet ve toplum nezdinde önem kazanmaları, iltizam sisteminin yaygınlaşması ile doğru orantılıdır. Bu doğrultuda Osmanlı maliyesi için önem arz eden sarraflar (burada kastedilen İstanbul sarraflarıdır), 17. yüzyılın sonlarında yapılan düzenlemelere (para sisteminde yaşanan reform, cizye 1slahatı gibi) paralel şekilde bir lonca etrafında teşkilatlandırılmışıı. ${ }^{7}$ Aynı dönemde iltizam sisteminin malikaneye evrilmesi, yani mukataaların kayd-1 hayat şartıyla mültezimlere verilmeye

Ömerül Faruk Bölükbaşı, "İstanbul Sarrafları (1691-1835)", Türk Kültürü İncelemeleri Dergisi, 30 (2014), s. 19-96.

5 Sarrafların katledilişi sadece 18. yüzyılla sınırlı değildir. 18. yüzyıl öncesi ve sonrasında da katledilen sarraflar bulunmaktadır. Örneğin H. 1071 yılında Haleb valisi Haseki Mehmed Paşa ile birlikte sarrafının da katledildiği Târîh-i Raşsid'de yazılıdır. Bkz. Târîh-i Râşsid ve Zeyli, c. I, haz. Abdülkadir Özcan vd., (İstanbul: Klasik Yay., 2013), s. 14. Bunun dışında, Sarraf Şabcı Bohor, Sarraf Tınazoğlu Dimitri, Sarraf Bağdadlı Haskil, ocak bâzergânı Cilyon (Çelbon) Yahudi, Düzoğullarından dört sarraf ve başkaları da 19. yüzyılda katledilmişlerdir. Bu kişiler için bkz. BOA. C.ML. 45/2084; MAD.d. 8253, 9759; C.AS. 42/1917; C.ML. 468/19037; Jamgoçyan, Les Finances de l'Empire Ottoman, s. 484; aynı yazar, Osmanl İmparatorluğu’nda Sarraflık, s. 182-183; Musa Kılıç, "Yeniçeri Ocağı ve Yahudiler Arasındaki İlişkiye Dair Bazı Tespitler”, Akademik Incelemeler Dergisi, X/2 (2015), s. 153-156.

Altın çağ vurgusu için bkz. Şahiner, The Sarrafs of İstanbul, s. 5; Cezar, "Osmanlı Devleti'nde Sarraflar", s. 179; aynı yazar, "The Role of the Sarrafs", s. 65.

6 Oktay Özel, Dün Sancısı: Türkiye'de Geçmiş Algısı ve Akademik Tarihçilik (İstanbul: Tarih Vakfi Yurt Yay., 2012), s. 62.

7 Sarrafların esnaf örgütü olarak teşkilatlandırılmaları için bkz. Bölükbaşı, "İstanbul Sarrafları (1691-1835)", s. 20. 
başlanması, 18. yüzyılın son çeyreğinde bir iç borçlanma yöntemi olan eshamın uygulamaya konulması ve uzun süren savaşlar, sarrafların önemlerini pekiştirmiştir. Bu bağlamda devletin yıkılışına kadar varlıklarını sürdüren sarraflar, Osmanlı yöneticileri, saray mensupları, çeşitli devlet kurumları (yeniçeri ocağı, darphane, madenler gibi), taşradaki yerel güç odakları ve ihtiyaçları doğrultusunda toplumun diğer bireyleri arasındaki ilişkilerde finansör ve aracı olarak önemli rol oynamışlardır.

Finansör ve aracı olarak çeşitli devlet kurumları ve toplumun farklı kesimleriyle, özellikle de yönetici elitlerle kurmuş oldukları ilişki ağları, sarrafları hem olumlu hem de olumsuz yönde etkilemiştir. Oluşturdukları bu ilişki ağlarının sarraflara olumlu etkisi, mali güç ve prestij kazanmaları noktasındadır. Olumsuz etki ise tam tersi doğrultuda sarraflık gediğine el konulmasından sürgüne, müsadereden hayatlarını kaybetme derecesine varan çeşitli cezai uygulamalarla karşı karşıya kalmak şeklinde olmuştur. ${ }^{8}$ Çalışmamız bu doğrultuda şekillenerek hayatlarını kaybeden, daha doğrusu katledilen sarraflara odaklanmaktadır. Sürgün, haps ve müsadere gibi farklı cezai uygulamalara maruz kalan sarraflar ise odak dışı bırakılmıştır. Sarraflarla ilgili yapılmış daha önceki çalışmalarda burada ele alacağımız örnekler hakkında bilgi bulunmakla birlikte konu bu bağlamda geniş olarak ele alınmamıştır. ${ }^{9}$ Bu açıdan örnek vakalara geçmeden önce, konunun daha iyi anlaşılması için, gayrimüslimlerin hukuki durumu ve siyaseten katl hakkında kısaca bilgi vermek yerinde olacaktır.

8 Sarrafların cezalandırılmaları hakkında bkz. Cezar, "Osmanlı Devleti'nde Sarraflar”, s. 189196.

9 Jamgoçyan, Les Finances de l'Empire Ottoman, s. 482-496; aynı yazar, Osmanlı Imparatorluğu'nda Sarraflık, s. 86-89; Şahiner, The Sarrafs of Istanbul, s. 61-62; Cezar, " Osmanlı Devleti'nde Sarraflar", s. 189-196; Edhem Eldem, "İstanbul: İmparatorluk Payitahtından Periferileşmiş Bir Başkente", Doğu ile Batı Arasında Osmanlı Kenti: Halep, İzmir ve İstanbul, çev. Sermet Yalçın (İstanbul: Türkiye İş Bankası Kültür Yay., 2012), s. 200-214; Kılıç, "Yeniçeri Ocağı ve Yahudiler", s. 153-156; Aykut Mustak, "Death of a Banker: Dimitrios Skanavis, d. 1788”, Debt and Dependence: Eight Annual Graduate History Symposium, University of Toronto, February 3-4, 2012; http://www.academia.edu/1225759/Death_of_a_Banker_Dimitrios_Skanavis_ d._1788 (Erişim 16 Eylül 2015); İsmail Hakkı Uzunçarşılı, Osmanlı Devleti Teşkilatından Kapukulu Ocaklar, c. I (Ankara: TTK, 1984), s. 407-410. 


\section{Gayrimüslimlerin hukuki durumu ve siyaseten katl}

Osmanlı Devleti'nin hukuki yapısı, farklı geleneklerden beslenmesine rağmen, İslam hukuku temelinde şekillenmiştir. Bu temel doğrultusunda İslam hukuku ilkelerine dayalı yapılan "zimmet" sözleşmesi çerçevesinde Osmanlı Devleti'nde gayrimüslimler din ve mezheplerine göre Rum, Ermeni, Yahudi gibi sınıflara ayrılarak, kendi cemaatleri içerisinde varlıklarını sürdürmüşlerdir. Bu bağlamda gayrimüslimler, özel hukuku ilgilendiren konularda (evlilik, boşanma, nafaka, miras vb.) kendi dini kurallarına tabidirler. Kamu hukukunu ilgilendiren konularda (yargılama, ceza, vergi vb.) ise, tıpkı Müslümanlar gibi, onlara da İslam hukuk kuralları tatbik edilebilmektedir. ${ }^{10} \mathrm{Bu}$ açıdan İslam ceza hukuku kapsamında değerlendirilen siyaseten katlin uygulanması noktasında da Müslimgayrimüslim arasında bir fark yoktur. ${ }^{11}$ Ahmet Mumcu da çalışmasında böyle bir ayrım yapılmadığına dikkat çekmiştir. ${ }^{12}$ Reaya ile birlikte, kamu hizmeti gören ve görevini kötüye kullanan Müslim-gayrimüslim askeri sınıf üyelerinin de ağırlıklı olarak çarptırıldığı siyaseten katl, ${ }^{13}$ "İslam hükümdarının mutlak otoritesine daya-

10 Osmanlı Devleti'nde yöneten ve yönetilen arasındaki ilişkiler bir mutabakata dayanmaktadır. Bu mutabakat çerçevesinde yüce Yaradan'ın emaneti olarak görülen reayanın padişaha mutlak itaati söz konusudur. Padişah da reayanın mutlak itaatine karşılık, tüm haklarını koruyarak, onların "emn ü amân” içinde kalmalarını sağlamakla yükümlüdür. Yönetenin bu yükümlülüğü tüm tebaa için geçerlidir. Gayrimüslimler de, İslam hukuku ilkelerine dayalı yapılan "zimmet” sözleşmesinin gereği olarak, yönetene itaat etmeleri karşılığında bu korumadan yararlanmaktadır. Hülya Taş, "Osmanlıda "Şikayet Hakkı”nın Kullanımı Üzerine Düşünceler”, Memleket Siyaset Yönetim, $2 / 3$ (2007), s. 187-188. Bu bağlamda zimmet sözleşmesi çerçevesinde din ve mezheplerine göre sınıflara ayrılarak varlıklarını sürdüren gayrimüslimler, kendi üyeleri tarafından seçilen ve padişah beratıyla atanan dini liderlerinin yönetiminde idare edilmişlerdir. Dini liderlere tanınan yetkiler, kendi cemaatinin dini, hukuki ve mali işlerini yürütmekle ilgilidir. Bu yetkiler gayrimüslimler için bir serbestiyet olarak algılansa da tam bir otonomi değildir. Daha geniş bilgi için bkz. Gülnihal Bozkurt, Gayrimüslim Osmanlı Vatandaşlarının Hukuki Durumu (1839-1914) (Ankara: TTK, 1996), s. 732; Yavuz Ercan, Osmanlı Yönetiminde Gayrimüslimler (Ankara: Turhan Kitabevi, 2001), s. 173-250; M. Macit Kenanoğlu, Osmanlı Millet Sistemi: Mit ve Gerçek (İstanbul: Klasik Yay., 2004), s. 27-90.

11 Siyaseten katl ile ilgili geniş bilgi için bkz. Ahmet Mumcu, Osmanl Devleti’nde Siyaseten Katl (Ankara: Phoenix Yayınevi, 2007).

12 Mumcu, Siyaseten Katl, s. 120.

13 Siyaseten katl cezasının hangi suçlar kapsamında verildiğini kesin olarak tespit etmenin imkansız olduğunu belirten Mumcu, siyasal erkin kamu yararı için çıkardığı kanun ve nizamlara aykırı hareketlerde bulunanlar ile görevini kötüye kullanan, toplumun ve devletin 
narak verdiği en ağır ceza" şeklinde tanımlanmaktadır. ${ }^{14}$ Bu ceza, tüm tebaasının canı ve malı üzerinde mutlak bir tasarruf yetkisi olan Osmanlı padişahı tarafından da tartışmasız uygulanmıştır. Sarrafların bu cezaya uğramasının temel belirleyicisi ise onların da askeri sınıftan sayılmaları olsa gerektir. ${ }^{15}$

Kamu hukuku açısından Müslim-gayrimüslim arasında bir ayrım olmamasına rağmen, Hagob L. Barsoumian, hükümet tarafından sarraflara, diğer gayrimüslimlerle aynı muameleye tabi tutulmayacaklarını güvence altına alan yasal bir düzenleme sağlandığına dikkat çekmektedir. Barsoumian’ın bahsettiği yasal düzenleme, darphane heyetinden oluşan sarraflar için özel bir mahkemenin kurulması ve sarraflara ait davaların burada görülmesidir. ${ }^{16}$ Barsoumian’ın belirttiği bu mahkeme, literatürde de değinilen, maliyenin işlerine bakan ve başında "mîrî kâtibi" denilen bir yetkilinin bulunduğu "maliye mahkemesi" olsa gerektir. ${ }^{17}$ Arşiv belgelerinden de sarraflara ait davaların bu tür bir mahkemede görüldügü anlaşıl-

zarar görmesinde rol oynayan kişilerin (devlet adamları, casuslar, eşkiyalar, kalpazanlar vs. gibi) bu cezaya çarptırılabileceğine vurgu yapmıştır. Bkz.: Mumcu, Siyaseten Katl, s. 44-45.

14 Mumcu, Siyaseten Katl, s. XIX.

15 Sarrafların askeri sınıftan sayılmaları hakkında bkz. Halil Sahillioğlu, "Askeri”, TDV İslâm Ansiklopedisi, 1991, III, s. 489. Y. Cezar da sarrafların serbest meslek zümresinden olmalarına rağmen, özel kişilerle olan işlerinin yanı sıra, devletle önemli ve derin ilişkileri nedeniyle bazılarının adeta birer devlet memuru statüsüne girdiklerini ve bu bağlamda onların bir kısmının "memur", bir kısmının da "yarı memur" statüsünde sayılabileceklerini belirtir. Bkz. Cezar, "Osmanlı Devleti'nde Sarraflar”, s. 192.

16 "Bankerlik mesleğinin doğası gereği sarraf ve alacaklısı -ki bu çoğu kez mültezim paşa olurduarasında ihtilaflar yaşanması kaçınılmazdı. Zımmi milletinin bir üyesi olarak sarrafin önemli bir yasal dezavantajı vardı: Şer’i mahkemede zımmilerin tanıklı̆̆ kabul edilmezdi ve bu yüzden normal mahkemede haklarm adil bir şekilde koruyamazlardı. Dahası, şeriat hukukuna göre borç verilen paradan kar elde etmek yasadışıdı ve tefecilik addediliyordu. Bu duruma çare olarak bükümet, sarrafların davalarının adil bir şekilde görülebileceği özel bir mabkeme kurdu. Batıl kaynaklarda "darphane heyeti" ş̧eklinde geçen bu özel mahkemenin hazine-i maliyeye yani Maliye Bakanlı̆̆ı’na mi, yoksa hazine-yi hassa yani Sultan Hazinesi'ne mi bă̆g olduğu açık değildir. Bu mahkemenin adli örgütlenme yapısı ne olursa olsun, sarraflar diğer gayrimüslim halkın sahip olamadiğı bazı haklara sahip olan, sultanın "imtiyazlar tanıdiğı” kişiler olmaya devam ettiler." Hagop L. Barsoumian, İstanbul'un Ermeni Amiralar Sinifi (İstanbul: Aras Yay., 2013), s. 107108.

17 Maliye mahkemesinde başbâki kulu vergi baş tahsildarı sıfatıyla maliye adına iddia makamı olarak bulunurdu. Verilen hükmün adil olup olmadığını Rumeli Kazaskeri incelerdi. Geniş bilgi için bkz. İsmail Hakkı Uzunçarşılı, Osmanlı Devletinin Merkez ve Bahriye Teşkilatı (Ankara: TTK, 1988), s. 361; Feridun Emecen, "Başbâki kulu”, TDV İlâm Ansiklopedisi, 1992, V, s. 127; aynı yazar, "Osmanlılarda Mali Kontrol Müessesesi Olarak Başbâki Kulluğu”, Feridun Emecen, Osmanlı Klasik Çağında Hanedan Devlet ve Toplum (İstanbul: Timaş Yay., 2011), s. 224; Ömerül 
maktadır. ${ }^{18}$ Ancak "eşrâf-ı kuzâtdan" olan mîrî̀ kâtibi" nin defterhanede, defterdar efendiler huzurunda düzenlediği "meclîs-i şer'-i hatîr"in ne kadar özel bir mahkeme olduğu ya da kadı mahkemesinden ayrı bir mahkeme şeklinde algılanıp algılanmadığı tartışmaya açıktır. Modern zamanlardaki gibi ayrı bir mahkeme binasının olmadığı göz önüne alındığında bu durumu devlet için mutlak derecede önemli olan mali işlerin daha hızlı yürütülmesi amacıyla düşünülmüş pratik bir çözüm olarak yorumlamak daha doğru olacaktır.

\section{8. yüzyılda katledilen sarraflar}

Öncelikle şunu belirtmek gerekir ki yaşanan katller sadece sarraflara özgü değildir. Devletle çalışan herkes aynı riski taşımaktadır. Bu açıdan "yüksek makamlar yüksek tehlikeler taşır"19 kuralı gereği sarrafların da her an "mîrîye zarar verdiniz"20 suçlamasıyla karşılaşmaları ve hayatlarını kaybetmeleri çok olağandır. Dolayısıyla, Barsoumian ve Cezar'ın vurguladığı gibi, devlet sarraflara yönelik planlı bir politika uygulamamıştır. ${ }^{21}$ Sadece arşiv kataloglarına bakılarak bile bu sonuç çok açık bir şekilde görülebilir. Diğer devlet görevlilerinin katl örneklerinin yanında katledilen sarraflar abartılacak bir oran teşkil etmezler. Bu, dönemin konjonktürü gereği yaşanan müsadere süreçleri için de böyledir. ${ }^{22}$

Faruk Bölükbaşı, 18. Yüzyılın İkinci Yarısında Darbhâne-i Âmire (İstanbul: Bilgi Üniversitesi Yay., 2013), s. 75-76.

18 Örneğin Bedros'la ilgili yapılan bir işlem şöyledir: “... Bedros nâm zimminin kâffe-i muhallefât ve zimemâtı cânib-i mîrîden kabzına mémûr olub husûmet-i rèy olunan hâlen başbâki kulu ser-bevvâbîn-i dergâh-ı 'âlî 'izzetlü İbrahim Ăga cânib-i şerî́at garrâdan mürsel mîrî kâtibi eşrâf-ı kuzâtdan Şeyhzâde Mehmed Emîn Efendinin sarây-ı defterîde ve defterdâr efendiler hazerâtına mahsûs odada 'akd eylediği meclîs-i şer'-i hatîrde husûs-ı merkûma...”. D.BŞM. 6886/92. Bir başka belgede de benzer ifadeler vardır. "...başbâki kulu ser bevvâbîn-i dergâh-ı 'âlî 'umdetül-e 'âlî İbrahim Ağa sâdır olan fermân-ı 'âlîlerine imtisâlen cânib-i şerî‘at garrâdan mürsel mîrî̀ kâtibi eşrâf-ı kuzâtdan Şeyhzâde Mehmed Emîn Efendinin saray-ı defteride ăga-yı mûmâ ileyhe mahsûs odada 'akd eylediği meclis-i şer'-i hatîrde... ” D.BŞM. 6900/106.

19 Barsoumian, Amiralar Sinifi, s. 108.

20 Cezar, “Osmanlı Devleti'nde Sarraflar”, s. 189.

21 Barsoumian, Amiralar Sinıfı, s. 110; Cezar, “Osmanlı Devleti'nde Sarraflar”, s. 192.

22 Müsadere, bir kişinin bütün maddi varlığına belirli şartlar dahilinde devlet adına el konulması anlamına gelmektedir. Osmanlı öncesinde de rastlanan bir uygulama olup ölüm halinde ya da bir ceza yöntemi olarak sürgün, katl gibi cezalarla birlikte tatbik edilmiştir. Başlangıçta devlete ihanet edenler ve asilerin cezalandırılmaları sırasında uygulanan müsaderenin 17. ve 18. yüzyıllardan itibaren kapsamı değişmiş ve mal-mülk sahibi, zengin kişilerin ölümleri halinde ya da hayattayken de malları müsadere edilmiştir. Ayrıca, devlet hizmetinde bulunmuş, servetinin 
Tablo 1'de de görüleceği üzere, yapmış olduğumuz araştırma kapsamında 18. yüzyılda katledilen sarraf sayısı 12'dir. Çeşitli kişi ve kurumların finansörleri olan bu kişiler, kaynaklarda sadece "sarraf" ve "bâzergân" olarak geçtikleri için bu listeye alınmıştır. Katle uğrayan Eflak voyvodası kapı kethüdası İstavraki $^{23}$ ve Livadiye kazası kocabaşısı İspirdaki ${ }^{24}$ gibi kişiler listeye dahil edilme-

kaynağında devlet malı olanların malları da müsadere edilmiştir. Devlete ihanet, devlet malını zimmetine geçirmek vb. gerekçelerin ileri sürülebildiği müsadere uygulaması, suistimallere rağmen, hem devlet için bir gelir kapısı olmuş hem de devlete karşı güç unsuru oluşturabilecek kişilerin dizginlenmesi için bir araç haline gelmiştir. 18. yüzyıldan itibaren yaşanan mali krizler dolayısıyla nisbi bir artış görülen müsadere uygulamasından sarraflar da payına düşeni almıştır. Geniş bilgi için bkz. Cahit Telci, "Osmanlı Devletinde 18. Yüzyılda Muhallefat ve Müsadere Süreci”, Tarih Incelemeleri Dergisi, XXII/2 (2007), s. 145-166; Tuncay Öğün, "Osmanlı Devleti'nde Müsadere Uygulamaları”, Osmanlı, c. 6: Teşkilat, ed. Güler Eren (Ankara: Yeni Türkiye Yayınları, 1999), s. 371-383; Cezar, “Osmanlı Devleti’nde Sarraflar”, s. 191-194; Bölükbaşı, Darbhâne-i Âmire, s. 173-175.

23 O. Jamgoçyan'ın listesinde, 1765 yılında Stavraki isimli Rum bir sarrafın katledildiği yazılıdır. Arşiv belgeleri, böyle bir kişinin katledildiğini doğrulamakla birlikte, İstavraki’nin sarraf olduğuyla ilgili bir bilgi sunmaz. Belgelerde geçtiği şekliyle "Istavraki oğlu Yorgaki" Eflak voyvodasının kapı kethüdasıdır. Şemdanizade de böyle bir bilgi vermektedir. Belgeler ayrıca, İstavraki’nin Eflak memleha ve gümrüğünün yarı hissesine ortak olduğunu yazmaktadır. İstavraki'nin neden katledildiği konusunda ise belgeler suskundur. Ancak Şemdanizade’ye göre İstavraki’nin katli, Eflak ve Boğdan ağnamı için ortak olduğu kasapbaşılar ile reayaya zarar vermesinden dolayıdır. Jamgoçyan ise, III. Mustafánın himayesinde ve aynı zamanda Eflak Beyi'nin sarrafı olan Stavraki'nin halkın ve yeniçerilerin kininin yanı sıra sarayın sırlarını ifşa etmek yüzünden katledildiğini belirtmektedir. Jamgoçyan, Les Finances de l'Empire Ottoman, s. 484; aynı yazar, Osmanlı Imparatorluğu'nda Sarraflık, s. 86, 182; Şem'dânî-zâde Fındıklılı Süleyman Efendi, Mür'i't-Tevârih, c. II/A, haz. Münir Aktepe (İstanbul: İstanbul Üniversitesi Edebiyat Fakültesi Yay., 1976), s. 7879; D.BŞM.ZMT.d. 13835, 13845; D. 2411/57-58; C.ML. 529/21693, 46/2104, 37/1698; C.DH. 166/8296; C.MTZ. 13/615.

24 O. Jamgoçyan’ın verdiği listeye göre, 1789 yılında, Spiridaki isimli Rum bir finansör katledilmiştir. Y. Cezar, Spiridaki (İspirdaki)'yi Mısır sarrafı olarak zikr eder. Ancak dönemin kroniklerinde ve arşiv belgelerinde Spiridaki sarraf olarak değil, Livadiye kazası kocabaşısı olarak geçmektedir. Spiridaki, reayaya zulm ve Rusya’ya casusluk yaptığı gerekçesi ile, devlete ihanetten katl olunarak malları müsadere edilmiştir. Jamgoçyan, Les Finances de l'Empire Ottoman, s. 484; aynı yazar, Osmanlı Imparatorluğu'nda Sarraflık, s. 86, 182; Cezar, "Osmanlı Devleti'nde Sarraflar”, s. 190; Ali Osman Çınar, "Mehmed Emin Edîb Efendi'nin Hayatı ve Târîh'i’” (doktora tezi), Marmara Üniversitesi Sosyal Bilimler Enstitüsü, 1999, s. 144; C.ML. 176/7485; D.BŞM.MHF. 81/15, 81/17, 82/13, 83/8, 87/118, 90/80, 92/56; HAT. 13/485, 13/495, 13/497, 14/580, 15/623, 15/667, 121/4946, 177/7813, 193/9442, 193/9456, 210/11343, 213/11657, 214/11738, 265/15393, 273/16035, 1382/54661, 1383/54685, 1383/54686, 1385/54895, $1390 / 55390$. 
miştir. Ayrıca şunu da belirtmek gerekir ki arşiv belgelerinde katle uğrayan sarraflara ait katl fermanlarına rastlanılmamıştır. Aşağıda da görüleceği üzere sadece Misır sarrafı Artin'in katliyle ilgili bir hatt-1 hümayun sureti mevcuttur. A. Mumcu, bu tür siyaseten katl belgelerinin bulunamayışının sebebini, katledilecek kişinin haberi önceden alıp bir çare üretmemeleri amacıyla gizlice kaleme alınmalarına ve emrin son derece gizli uygulanmasına bağlar. Ona göre bazı katllerin fermansız icra edilmesi de bu tür belgelerin olmayışının başka bir nedenidir. ${ }^{25}$

Tablo 1: 18. yüzyılda katledilen sarraflar ${ }^{26}$

\begin{tabular}{|l|l|l|l|}
\hline İsmi & Görevi & $\begin{array}{l}\text { Katl } \\
\text { tarihi }\end{array}$ & Aidiyeti \\
\hline David (David Zonana) & Yeniçeri ocağı bâzergânı & 1746 & Yahudi \\
\hline $\begin{array}{l}\text { Musa (Moşe) (David'in } \\
\text { akrabası) }\end{array}$ & Bağdat ocak bâzergânı & $1748-49$ & Yahudi \\
\hline Yakub (Yakub Hovanesyan) ${ }^{27}$ & $\begin{array}{l}\text { Darüssaade Ağası Beşir Ağa’nın } \\
\text { sarrafı }\end{array}$ & 1752 & Ermeni \\
\hline
\end{tabular}

25 Mumcu, Siyaseten Katl, s. XXIII.

26 Jamgoçyan'ın listesinden hareketle kaynaklar ve literatürde yer alan bilgiler ışığında tarafımdan hazırlanmıştır. Karşılaştırma için bkz. Jamgoçyan, Les Finances de l'Empire Ottoman, s. 484; Jamgoçyan, Osmanlı Imparatorluğu'nda Sarraflık, s. 182-183.

27 O. Jamgoçyan'ın çalışmasında yer alan listenin ilk sırasında, Musa isimli Ermeni bir sarrafın 1746 yılında katledildiği gözükmektedir. Bkz. Jamgoçyan, Les Finances de l'Empire Ottoman, s. 484; aynı yazar, Osmanlı Imparatorluğu’nda Sarraflık, s. 182. Ancak biz kaynaklarda bu tarihte katledilen Musa isimli Ermeni bir sarrafa rastlamadık. Bu konuda kesin bir yargıda bulunmak mümkün olmamakla birlikte, Mür'i't-Tevârih'te David'in akrabası olarak geçen Moşa (muhtemelen Musa) ile Musa'nın aynı kişiler olması muhtemeldir. Dolayısıyla bu ihtimal dahilinde Musa, Ermeni değil, Yahudi'dir. Kaynaklarda yer alan bilgiye göre Tiryaki Mehmed Paşa'nın Bağdat valiliğine atanmasından sonra katledildiği için katl tarihi de 174849 aralığı olsa gerektir.

28 Mür'ìt-Tevârih ve Târîh-i İzzîde katledilen kişi Agob olarak geçmektedir. Ancak arşiv belgelerinde Yakub’un maktul olduğu yazılıdır. Agob ise, Yakub'un kardeşi olarak belgelerde zikredilir. Bkz. Şem'dânî-zâde, Mür'i't-Tevârih, s. 34; Süleyman İzzi, Târîh-i İzzî (İstanbul: 1199), s. 279; D.BŞM.MHF. 41/66. Jamgoçyan, Yakub Hovanesyan'la aynı dönemde Dzeron Amira adında bir darphane sarrafı ile Yakub Hovanesyan'la bağlantısı bulunan 10 sarrafın daha katledildiğini belirtir. Ancak arşiv belgeleri ve dönemin Osmanlı kronikleri bu konuda suskundur. Bkz. Jamgoçyan, Osmanl İmparatorluğu’nda Sarraflık, s. 86, 182. Barsoumian ise, Dzeron Amira’nin katedilmekten ziyade eceliyle öldügüünü belirtir. Barsoumian, Amiralar Sinifi, s. 94. 


\begin{tabular}{|l|l|l|l|}
\hline Kazer (Ğazar Amira $\left.{ }^{28}\right)^{29}$ & $\begin{array}{l}\text { Koca Ragıb Mehmed Paşånın } \\
\text { sarrafı }\end{array}$ & 1763 & Ermeni \\
\hline 4 isimsiz sarraf & & 1764 & Ermeni \\
\hline İsak & Yeniçeri ocağı bâzergânı & 1784 & Yahudi \\
\hline Bedros (nam-ı diğer Petraki) & Darbhâne-i Âmire sarrafı & 1786 & $\begin{array}{l}\text { Ermeni/ } \\
\text { Rum }^{30}\end{array}$ \\
\hline $\begin{array}{l}\text { Sakızlı Dimitri (Dimitri } \\
\text { Skanavi) }\end{array}$ & Esma Sultan'ın sarrafı & 1788 & Rum \\
\hline Artin (Harutyun Amira) $)^{31}$ & Mısır sarrafı & 1790 & Ermeni \\
\hline
\end{tabular}

29 "Amira" kelimesi, Ermeniler tarafından milletin lideri olarak görülen ve Osmanlıların çeşitli biçimlerde ayrıcalıklar tanıdığı varlıklı kişi/kişiler için kullandıkları bir saygınlık ünvanıdır. Geniş bilgi için bkz. Barsoumian, Amiralar Sınıfi, s. 59-78; Şahiner, The Sarrafs of İstanbul, s. 88, 89; Cahit Külekçi, "Ermeni Kimliğinin Dönüşüm Süreci ve Amira Sınıfının Oluşumu”, Hikmet Yurdu, 6/12 (2013), s. 101-117. Külekçi makalesinin girişinde “amira” nın Ermeni ileri gelen ailelerindeki bazı şahıslara Osmanlı Devleti tarafından verilen bir ünvan olduğunu belirtmektedir. Ancak arşiv belgelerinde ve diğer kaynaklarda bu bilgiyi destekleyen herhangi bir veri yoktur.

30 Kazer, Barsoumian'ın çalışmasında Ğazaros Movsesyan olarak zikredilirken, Jamgoçyan'ın çalışmasında Ğazar Amira Harutyunyan olarak belirtilir. Mesut Aydıner ise Kazer Amira Arzumanyan (d'Arutin) olarak verir. Bkz. Barsoumian, Amiralar Sınıfi, s. 108; Jamgoçyan, Osmanlı İmparatorluğu’nda Sarraflık, s. 86, 182; Mesut Aydıner, "XVIII. Yüzyılın İkinci Yarısında Osmanlı Ermenileri ve Bazı Önemli Sîmâlar”, Hoşgörü Toplumunda Ermeniler, c. III, haz. Metin Hülagü vd. (Kayseri: Erciyes Üniversitesi Yay., 2007), s. 194.

31 Belgelerde zimmi olarak zikredilen Bedros (nam-1 diğer Petraki)'un Rum mu Ermeni mi olduğuyla ilgili bir netlik yoktur. Barsoumian'a göre Petraki Çelebi, Katolik Ermeni'dir. Eldem'in makalesinde ise Rum olarak geçmektedir. Jamgoçyan ise vermiş olduğu listede Rum olarak Petraki'den bahsederken kitap içerisinde Ermeni olarak zikretmektedir. Bkz. Barsoumian, Amiralar Sınıfi, s. 94; Eldem, "İstanbul", s. 280; Jamgoçyan, Osmanlı Imparatorluğu'nda Sarraflık, s. 77, 182. Bedros'un hem Ermeni hem de Rum (Petraki) ismi taşıyor olması onun Christine M. Philliou'nun bahs ettiği Helenleşmiş (Rumlaşmış) Ermenilerden olma ihtimalini akla getiriyor olsa da bu konuda kesin bir şey söylemek mümkün gözükmüyor. Bkz. Christine M. Philliou, Biography of an Empire: Governing Ottomans in an Age of Revolution (London: University of California Press, 2011), s. 202.

32 Jamgoçyan, Artin dışında, 1795 yılında Harutyun Amira Erganyan adında bir sarrafın daha katledildiğini yazar. Ancak Osmanlı kaynakları bu konuda sessiz kalmaktadır. Bkz. Jamgoçyan, Osmanlı Imparatorluğu’nda Sarraflık, s. 182. 
Yukarıdaki tabloda görüldüğü üzere 18. yüzyılda kaynaklara yansıyan katledilen sarraflardan ilki I. Mahmud döneminde yeniçeri ocağı bâzergânlığ ${ }^{33}$ görevinde bulunmuş olan David Zonana ${ }^{34}$ isimli bir Yahudidir. David'in ne zaman ocak bâzergânı olduğuyla ilgili bir kesinlik olmamakla birlikte 1736 yılından itibaren katledilişine kadar bu görevi sürdürdüğü Mür'itt-Tevârih'te yer alan bilgiden anlaşılmaktadır. ${ }^{35}$ David'in ocak bâzergânlığı görevini elde edecek güce nasıl ulaştığı, bu göreve yükselişinin ardındaki kişilerin kim ya da kimler olduğuyla ilgili bir yorumda bulunamıyoruz. Fakat, Seyyid Hasan Paşa'nın ${ }^{36}$ sadrazamlıktan azledilmesinden (1746) sonra katle uğramış olması, David'in yükselişinde rol oynayan ana aktörlerden birinin Hasan Paşa olduğu izlenimini bize vermektedir. ${ }^{37}$ Hasan Paşa ile David'in ilişkisi muhtemelen Hasan Paşa'nın kariyerinin başlangıç noktası olan yeniçeri ocağına dayanmaktadır. Aralarındaki yakınlık ise Hasan Paşa’nın kariyer basamaklarını tırmandığı yeniçeri ağalığı (1738), vezirlik (1739) ve sadrazamlık (1743-1746) dönemlerinde daha da kuvvetlenmiş olsa gerektir. ${ }^{38}$

33 Yeniçerilerin ayni ve nakdi ihtiyaçlarını finanse etmekle görevli olan ocak bâzergânlığı hakkında geniş bilgi için bkz. Uzunçarşıll, Kapukulu Ocakları, s. 407-410; Süleyman Kaya, "XVIII. Yüzyıl Osmanlı Toplumunda Kredi" (yüksek lisans tezi), Marmara Üniversitesi Sosyal Bilimler Enstitüsü, 2003, s. 21-42; Kılıç, "Yeniçeri Ocağı ve Yahudiler", s. 143-164.

34 David ile ilgili ansiklopedik bilgi için bkz. Encyclopaedia Judaica, 2007, XXI, s. 668. David, katledilen tek ocak bâzergânı değildir. Aşağıda da değineceğimiz gibi I. Abdülhamid döneminde ocak bâzergânlığı yapan İsak, II. Mahmud öncesinde bu görevi sürdüren Cilyon ve onun oğlu Yakovaçi katledilen diğer ocak bâzergânlarıdır. Bkz. Kılıç, "Yeniçeri Ocağı ve Yahudiler”, s. 153-156; C.AS. 1142/50743, 1142/50785; C.AS. 42/1917. Jamgoçyan, David'in üyesi olduğu Zonana ailesinin 1741'den 1770'e kadar ocak bâzergânlığı yaptığını belirtir. Jamgoçyan, Osmanl Imparatorluğu’nda Sarraflık, s. 58. Yusuf Belasel ise, "Osmanlı ve Türk Yahudileri" adlı eserinin 45. sayfasında, Acıman ailesinden Yeşaya Acıman'ın 1730'dan 1773’e kadar Yeniçeri sarraflığı yaptığını ve suistimalleri gerekçesiyle katledildiğine dikkat çeker. Ancak bu bilgiyi hangi kaynaktan aldığını belirtmez. Aynı eserin başka bir sayfasında ise yine Yeşaya Acıman'ın Acıman ailesinin son maliyecisi olduğu ve yeniçerileri desteklediği gerekçesi ile ocağın kaldırılmasından sonra katledildiğini belirterek kendi içinde çelişir. Bkz. Yusuf Belasel, Osmanl ve Türk Yahudileri (İstanbul: Gözlem Gazetecilik Basın ve Yayın A.Ş., 2004), s. 45, 47. Aynı bilgiyi M. Aydıner de aktarır. Bkz. Aydıner, “Osmanlı Ermenileri”, s. 185.

35 Şem'dânî-zâde, Mür'it-Tevârih, s. 133-134.

36 Seyyid Hasan Paşa ile ilgili bkz. Mehmed Süreyya, Sicil-i Osmanî, c. 2, haz. Nuri Akbayar (İstanbul: Tarih Vakfi Yurt Yay., 1996), s. 643-644; İsmail Hakkı Uzunçarşılı, Osmanl Tarihi, c. 4/2 (Ankara: TTK, 2003), s. 360-363; Fikret Sarıcaoğlu, "Hasan Paşa, Seyyid”, TDV İslàm Ansiklopedisi, 1997, XVI, s. 339-340.

37 Encyclopaedia Judaica, XXI, s. 668; Kılıç, "Yeniçeri Ocağı ve Yahudiler”, s. 156.

38 Mehmed Süreyya, Sicill-i Osmanî, c. 2, s. 643-644; Uzunçarşılı, Osmanlı Tarihi, c. 4/2, s. 360-363; Sarıcaoğlu, "Hasan Paşa, Seyyid”, s. 339-340. 
Ancak aralarındaki bu bağ Hasan Paşa’nın sadrazamlıktan azl edilmesinden sonra David'in idamına da (1746) yol açmıştır. ${ }^{39}$

Şemdanizade'nin verdiği bilgilerden, David'in devlet malına zarardan dolayı katledildiği anlamı çıkmakla birlikte aslında Hasan Paşa’nın yerine sadrazamlığa getirilen Tiryaki Mehmed Paşa ile aralarında geçmişe dayanan husumetin, onun katlinde en büyük rolü oynadığı açık şekilde görülmektedir. ${ }^{40}$ Şöyle ki Tiryaki Mehmed Paşa 1736 tarihinde Avusturya ve Rusya ile yapılan savaşlar sırasında ağa kapısı yazıcıllı̆ıından başyazıcıllğa yükseltilerek sefere katılmakla görevlendirilir. Bu görevde, Padişah'ın Mehmed Paşa’ya tenbihi şudur: “...orduya vardıkda, göreyim seni, ulûfeyi zâyi' etme ve zâid esâmeleri bulup ulûfesini verme....". Verilen görevi layıkıyla yerine getiren Mehmed Paşa, dağıtılması gereken ulufeden bin iki yüz kese arttırır ve elde edilen fazla parayı hazineye aktarır. Ancak bu durum o sırada ocak bâzergânı olan David'in zararınadır. Çünkü David fazla olan esamelerin bir kaç yüz kesesinin kendisine kalmasını beklerken, Tiryaki buna engel olmuştur. Dolayısıyla kar elde etmek yerine zarara uğramak David'i memnun etmez ve Tiryaki'den bir şekilde intikam almak ister. Nüfuzunu kullanarak bunu gerçekleştirir ve Tiryaki Mehmed'i yazıcılıktan çıkarttırarak daha düşük bir göreve sürülmesini sağlar. Ancak sürgün, Vezir Kethüdası Osman'ın devreye girişiyle gerçekleşmez. Osman Kethüda sayesinde Divan-ı Hümayun hâcegânı arasına giren Tiryaki Mehmed Paşa, zamanla sadrazamlığa kadar yükselir. ${ }^{42}$ Öyle anlaşıllyor ki bu küçük olay David'le Tiryaki Mehmed Paşa arasındaki düşmanlığın kıvılcımını yakmıştır.

Küçük bir kıvılcımla başlayan bu düşmanlık zamanla daha da şiddetlenmiş gibidir. Öyle ki David ve Mehmed Paşa arasında geçen “....sen bana ettiğin gadri bilir misin, ahdim olsun vezîr olur-isem seni katl edeyim... heman sen vezîr ol da

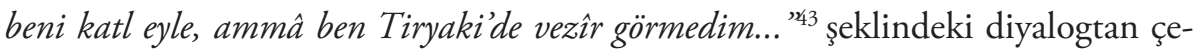

39 Şem’dânî-zâde, Mür'i't-Tevârih, s. 134; Uzunçarşılı, Osmanlı Tarihi, c. 4/2, s. 364; aynı yazar, Kapukulu Ocakları, s. 408.

40 Şem'dânî-zâde, Mürï't-Tevârih, s. 56. Tiryaki Mehmed Paşa ile ilgili bkz. Mehmed Süreyya, Sicill-i Osmanî, c. 4, (İstanbul: Tarih Vakfı Yurt Yay., 1996), s. 1075; Uzunçarşılı, Osmanlı Tarihi, c. 4/2, s. 363-367.

41 Şem'dânî-zâde, Mür'i't-Tevârih, s. 133-134; Uzunçarşılı, Osmanlı Tarihi, c. 4/2, s. 363-364; aynı yazar, Kapukulu Ocakları, s. 408.

42 Şem'dânî-zâde, Mür'it-Tevârih, s. 133-134; Uzunçarşılı, Osmanlı Tarihi, c. 4/2, s. 363-364; aynı yazar, Kapukulu Ocakları, s. 408.

43 Şem'dânî-zâde, Mür'it'-Tevârih, s. 134; Uzunçarşılı, Osmanlı Tarihi, c. 4/2, s. 364; aynı yazar, Kapukulu Ocaklar, s. 408. 
kişmenin boyutları çok iyi anlaşılmaktadır. Mehmed Paşa bu ahdini sadrazam olduktan sonra gerçekleştirme firsatı bulmuştur. Mührü aldıktan sonra bu vakayı padişaha anlatan Mehmed Paşa, bununla yetinmeyip David'in ocak mensuplarına da hakaret ettiğini belirterek padişahı ona karşı doldurur ve katli için onay alır. David, sadrazamı tebrik için beklerken yakalanarak önce bostancıbaşılara ait odada haps edilir ve ardından boğdurularak denize atılır. ${ }^{44}$ Böylece Mehmed Paşa intikamını almıştır. David'in İngiliz himayesinde oluşu bile onun katline bir çare teşkil etmemiştir. ${ }^{45}$

Kaynaklarda Tiryaki Mehmed Paşa’nın David'e olan kini David'in ölümünün ardından da devam etmiş gibi gözükmektedir. Bu kez Tiryaki Mehmed Paşa’nın gazabına uğrayan David'in akrabası olan Bağdat ocak bâzergânı Musa (Moşa veya Moşe)'dır. Sadrazamlıktan azlinin ardından atandığı Bağdat valiliğinde Tiryaki Mehmed Paşa, Bağdat ocaklısına zarar verdiği gerekçesiyle Musa’yı da katl ettirir. ${ }^{46}$ Şemdanizade bu katlleri "dîn-i mübîne hizmet ${ }^{\text {"47 }}$ olarak addeder.

Görüldügüü üzere David ve akrabası Musa’nın katlleri sadece devlet malına zarardan dolayı gerçekleşmemiştir. Şemdanizade'nin verdiği bilgiler ışığında her ikisinin de yukarıda değindiğimiz ekonomik artığa el koyma mücadelesi bağlamında bir hizip çatışmasına kurban gittiğini açıkca söylemek mümkündür.

44 Şem'dânî-zâde, Müri’t'-Tevârih, s. 134; Uzunçarşıll, Osmanlı Tarihi, c. 4/2, s. 364; aynı yazar, Kapukulu Ocakları, s. 408. Cemal Kafadar, "Britanya Fahrî Dragomanı" beratına sahip olan bezirgânın "bütün mevkiler" üzerinde tasarruf sahibi olduğunu ve yeniçerilerin arasına girmeye talip olanların bütün başvurularının ona yapıldığını belirtmektedir. Ayrıca bezirgânın ocağa ait defterleri gözü gibi muhafaza ettiği ve esamesi olanların sayısı hakkında hiç bir bilgi sızmasına müsaade etmediğini ve dolayısıyla zaman zaman kendisinden bilgi isteyen ya da ıslahat girişiminde bulunan Osmanlı yetkilileri ile çatıştı̆̆ını belirtmektedir. Bkz. Cemal Kafadar, "Yeniçeriler ve Osmanlı Döneminde İstanbul'un Ayaktakımı: Yok Yere mi Asiydiler?", Osmanl Dünyasında Kimlik ve Kimlik Oluşumu: Norman Itzkowitz Armağanı, ed. Baki Tezcan ve Karl K. Barbir, çev. Zeynep Nevin Yelçe (İstanbul: Bilgi Üniversitesi Yay., 2012), s. 140-141.

45 Kafadar, "Yeniçeriler ve Osmanlı”, s. 140; Eldem,"İstanbul”, s. 203; Jamgoçyan, Osmanlı Imparatorluğu'nda Sarraflık, s. 79. Maurits H. van den Boogert'e göre, sarrafların konsolosların dragoman listeleri içerisinde yer alarak yabancı devletlerin himayesine girmeleri, ticari bir ayrıcalıktan ziyade imtiyazlı bir statü elde etmenin en emin yoludur. Bkz. Maurits H. van den Boogert, Kapitülasyonlar ve Osmanlı Hukuk Sistemi: 18. yüzyılda kadılar, konsoloslar ve beratlılar, çev. Ali Coşkun Tuncer (İstanbul: Türkiye İş Bankası Yay., 2014), s. 70. Ancak bu, onlara tam bir koruma sağlamamıştır. Sarrafların hangi devletlerin himayesinde oldukları ile ilgili geniş bilgi için bkz. Jamgoçyan, Osmanlı İmparatorluğu’nda Sarraflık, s. 75-79.

46 Şem’dânî-zâde, Mür'i't-Tevârih, s. 134.

47 Şem'dânî-zâde, Mür'it-Tevârih, s. 134. 
Ermeni sarraf Yakub Hovanesyan ${ }^{48}$ için de benzer bir son söz konusudur. O da David'le aynı kaderi paylaşmaktan kurtulamaz. Ancak bir fark vardır. David, hamisini kaybetmesinin ardından kendi çekişmelerinin kurbanı olurken Hovanesyan, sarayın en güçlü kişisiyle çalışmanın bedelini ödemiştir. Daha doğrusu o, Daarüssaade ağası (1746-1752) Beşir Ağa’nın ${ }^{49}$ hazinedarı Süleyman Ağa ve kethüdası Arnavud Mehmed Efendi gibi Beşir Ağa'nın siyasi çıkarları ve bu çıkarlar doğrultusunda yaşanan mücadelelerin kurbanıdır. ${ }^{50}$

Fransız beratlısı olan Yakub'un ${ }^{51}$ hikayesi önemli Ermeni sarrafların çoğu gibi Eğin (Kemaliye)'de ${ }^{52}$ başlamış ve İstanbul'da noktalanmıştır. Onun Eğin'de başlayıp İstanbul'da noktalanan hayatının arkasındaki kişi yine Eğinli olan Harutyun Hovivyan Amira’dır. Hovivyan Amira’nın 17. yüzyılın sonlarına doğru Eğin'den getirtmesiyle değişmeye başlayan Yakub’un yaşamı, Vezir Han'da elde edilen sarraflık gediğiyle farklı bir boyut kazanmıştır. ${ }^{53}$ Asıl yükselişi ise Daarüssaade ağası Beşir Ağa’nın hazinedarı Süleyman Ağa ile tanışmasından sonradır.

48 Yakup Hovanesyan'ın çarpıcı hayat öyküsü ile ilgili bkz. Jamgoçyan, Les Finances de l'Empire Ottoman, s. 485-496; aynı yazar, Osmanlı Imparatorluğu’nda Sarraflık, s. 44-50; Eldem, "İstanbul", s. 200-214.

49 Bu Beşir Ağa, 1746'da Darüssaade ağası olan Moralı Beşir Ağa'dır. 1752 yılında katle uğramıştır. Bkz. İsmail Hakkı Uzunçarşılı, Osmanlı Tarihi, c. 4/1 (Ankara: TTK 1995), s. 332334; Abdülkadir Özcan, "Beşir Ağa, Moralı”, TDV İslâm Ansiklopedisi, 1992, V, s. 555-556; Jane Hathaway, Osmanlı Sarayının En Ünlü Harem Ağası: Hacı Beşir Ağa, çev. Hazal Yalın (İstanbul: Kitap Yayınevi, 2014), s. 102-103.

50 Şem'dânî-zâde, Mür'i't-Tevârih, s. 164-168. Tarih-i İzzi, 276-281. Jamgoçyan Yakup Hovanesyan'ın bir başka Ermeni sarraf Serpos Erevanents ile birbirlerinden nefret ettiklerini ve dolayısıyla bir çekişme içinde olduklarını belirtir. Jamgoçyan, Osmanlı Imparatorluğu’nda Sarraflik, s. 44, 46.

51 Jamgoçyan, Osmanlı İmparatorluğu'nda Sarraflık, s. 79.

52 11. yüzyılda Vaspuragan'dan gelen bir grup Ermeni tarafından kurulduğu varsayılan Eğin (Kemaliye), Osmanlı Devleti'nde öne çıkan önemli sarrafların çoğunun memleketiydi. Dağlık bir coğrafyada kurulan Eğin'den bu kadar çok sarrafın çıkmasında, muhtemelen, bölge insanının ticaretle uğraşması ve para kazanmak için, başta İstanbul olmak üzere büyük kentlere yaptıkları sürekli göç ile birlikte aralarında bölgeciliğe dayalı kurmuş oldukları dayanışma ağları etkili olmuş olabilir. Bkz. Barsoumian, Amiralar Sinıfı, s. 70-71; Eldem, "İstanbul”, s. 206, 280; Zeki Arıkan, "Eğin Kasabası'nın Tarihsel Gelişimi”, OTAM, 12 (2001), s. 2-3.

53 Çemberlitaş'da bulunan Vezir Hanı, 17. yüzyılda Köprülü Fazıl Ahmet Paşa tarafindan yaptırılmıştır. Bünyamin Demir, XIX. Yüzyılda Tarihi Yarımada Hanlarının Ekonomik Yönü (doktora tezi), Marmara Üniversitesi Sosyal Bilimler Enstitüsü, 2010, s. 55-56. Bu han, sarrafların yoğun olarak bulunduğu sur içinin ana ticaret ve finans merkezi olan Kapalıçarşı merkezli bölgede yer almaktadır. Bölükbaşı, "İstanbul Sarrafları (1691-1835)”, s. 33. 
Bu tanışma, Süleyman Ağa’nın kardeşi Anna ile evlenmesinin ardından gerçekleşmiştir. ${ }^{54}$ Süleyman Ağa sayesinde sarayın en güçlü kişilerinden Darüssaade ağası Beşir Ağa’nın hizmetine giren Yakub Hovanesyan, bu yakınlaşmayla bir yandan ekonomik ve siyasi gücünün doruklarına ulaşırken, bir yandan da farkında olmadan kendi felaketine doğru sürüklenmiştir.

Hovanesyan'ın böyle bir felakete sürüklenmesi, Beşir Ağa’nın I. Mahmud üzerinde sahip olduğu büyük nüfuzu ve bu nüfuzunu siyasi hırsları ile birleştirmiş olması dolayısıyladır. Şemdanizade’nin verdiği bilgiden Beşir Ağa’nın bu nüfuzunu çok iyi kullandığı rahatlıkla anlaşılmaktadır. ${ }^{55}$ Beşir Ağa elde ettiği bu güçle sadrazam tayinlerinin gerçekleşmesinde bile rol oynarken hem kendisi hem de adamlarının vezir, kadı, müftü gibi kişilere yapmış oldukları davranışlar, onun adamlarıyla birlikte önemli düşmanlar kazanmasına neden olmuştur. Çeşitli kademelerden yönetici elitler (sadrazamlar, vezirler vb.), ulema sınıfı ve yeniçerilerin de dahil olduğu bu düşmanlar, sadece Beşir Ağa için değil etrafındaki herkes için bir risk oluşturmuştur. Yakub Hovanesyan da bu gruba dahildir. ${ }^{56}$

Jamgoçyan, Les Finances de l'Empire Ottoman, s. 485; aynı yazar, Osmanl İmparatorluğu'nda Sarraflik, s. 45; Eldem, "İstanbul", s. 206.

54 Jamgoçyan, Les Finances de l'Empire Ottoman, s. 485; aynı yazar, Osmanlı Imparatorluğu’nda Sarraflik, s. 45; Eldem, a.g.m., s. 207-208, 278-279.

55 "Hacı Beşir Ağa fevtinden berü altı sene Dârü's-sa'âde A ̆gası oldukta rızâ-yı pâdişâhîde kıyâm eder. Lâkin Süleyman nâm kakavanı hazinedar ve Arnavud Mehmed Ăga nâm bî-îmânı kethüda ve Köstendilli Hasan Efendi nâm sâhib-i sâmân müsâhib edüp semt-i celb-i mâlî îzah ettiklerinde [...] Vezîr'den ve Müfti'den ve Yeniçeri Ocă̆g'ndan ve sẩirinden matlûbu olan husûs bilâ te’hîr vücûda geldiğinden, her mansıbın üçer beşer tâlibi, tahammülünden ziyâde meblâğ arz ettikde, zâten ve zamânen liyâkat ve istihkaka nazar etmeksizin ziyâde veren tercih olunup [...] cümle erkân-ı devlete hâkim olduğuna kanâat etmeyüp, sadrâzamlara dahi tahakküm ve benim çırağımsın edâsın iş̧âr ve sâhib-i mühr olanlar azl ve nasbi Ağa’nın yedinde olduğunu [...] Vezîr olan mahkûm olup, sadrin hükmünü veremiyecek, canından bîzâr olur ve vezîrin aczini görenler Ağàya adâvet-i kalbî hâsıla etmişleridi. Lâkin Ağa kendi alup, Süleyman'a ve Arnavud Mehmed'e aldırıp cem' ettiği mâlı [...] her gün pâdişâhâ arz etmekle Ağa pâdişâhın mahbûbu olmuşidi. Bu sebepden hayr-hâh olanlar, pâdişâha ifâdeye muktedir değilidi [...] sẩir kimesne şöyle dursun, üç tuğlularn sallamayup vüzerâya za'ìm nazar ile edâ ederleridi. Zikri sebk ettiği üzre Mustafa Paşa mührü alıcak, gerçi ben hassaten Ağa’nın çıră̆ı oldum; amma şân-ı vezâret eslâfimdan ziyâde tevâzu've tezellüle mâni' eslâfim gibi olsam azl ve tenkîl ve fitne ihtimâli var [...]. Pâdişâh̆n Ăgaya muhabbeti var deyü, bu hüccetleri kimesne pâdişâha ifâde edemez. Fitne zuhûr eder ise, pâdişâha ve devlete mazarrat olur, fitne olmasa dahi bu mertebe rüssvet ile kârhâne-i devletin nizâmı mubtel olur. "Şem'dânî-zâde, Mür'it-Tevârih, s. 164-168. İzzi Tarihi'nde de Beşir Ağa ve adamları ile ilgili benzer anlatılar mevcuttur. Bkz. Tarih-i $\dot{I}_{z z i}$, s. 276-281.

56 Eldem, “İstanbul”, s. 207-208, 278-279; Özcan, “Beşir Ağa, Moralı”, s. 555-556; Hathaway, Hacı Beşir A ̆ga, s. 102. 
Beşir Ağa ve etrafındakiler için bu risk, ilk olarak 1748 yılında İstanbul'da yaşanan kundakçılık olayları sırasında kendini göstermiştir. Ancak Beşir Ağa, olaylara karışanları idam ettirerek kendine karşı yapılan bu ilk girişimin üstesinden rahatlıkla gelebilmiştir. ${ }^{57} 1752$ 'deki ikinci girişim ise Beşir Ağa ve adamları için bir yıkım olmuştur. Her ne kadar I. Mahmud, çıkan olayları Sadrazam Mehmed Paşa’yı (1750-1752) görevinden alarak yatıştırmaya çalışsa da Beşir Ağa'nın kurtuluşuna çare olamamışır. Şeyhülislamın telkinleri ve Sadrazam Bahir Mustafa Paşa'nın (1752-1755) arzı sayesinde gönülsüzce de olsa Beşir Ağànın ortadan kaldırılmasını kabullenmiştir. Bu kabulleniş Beşir Ağa ve adamları için bir trajedi olmuştur. Beşir Ağa ile birlikte hazinedarı Süleyman Ağa, kethüdası Mehmed Efendi ve sarrafi Yakup Hovanesyan katledilerek mallarına el konulmuş, ${ }^{58}$ diğer adamları da sürgüne gönderilmiştir. ${ }^{59}$

Bu dönemde katle uğrayan sarraflardan bir diğeri de Ermeni asıllı Kazer (ö. 1763)'dir. ${ }^{60}$ Yakub Hovanesyan gibi o da üst düzey bir yönetici elitle çalışmanın bedelini canıyla ödemiştir. Kazer' in hizmet ettiği kişi ise Sadrazam Koca Ragıb Mehmed Paşa'dır (1757-1763) ${ }^{61}{ }^{1}$ Kazer'in Mehmed Paşa ile nasıl tanıştığı, onun yükselişi ile birlikte mi yükseldiği konusunda elimizde bir veri bulunmamaktadır. Ancak bilinmektedir ki Ragıb Paşa döneminde Ermeniler, özellikle de saray ve devlet adamları ile iş yapan sarraflar, önemli görevler elde etmişlerdir. ${ }^{62}$ Kazer de

57 Jamgoçyan, Osmanlı İmparatorluğu’nda Sarraflık, s. 45-46; Eldem, "İstanbul”, s. 279.

58 Beşir Ağa, Süleyman Ağa ve Yakub Hovanesyan'ın el konulan malları ile ilgili bkz. MAD.d. 10354, s. 440-507; D.BŞM.MHF.d. 12602, 12602, 12605, 13698; D.BŞM.MHF. 41/39, 41/40, 41/41, 41/43, 41/44, 41/46, 41/66, 42/30; D.BŞM.ZMT.d. 13802, 13805, 13807 , 13813, 13915; D. 2217; KK. d. 2447.

59 Şem'dânî-zâde, Müri't-Tevârih, s. 164-168; Tarih-i İzzi, s. 276-281; Jamgoçyan, Les Finances de l'Empire Ottoman, s. 485-491; ayn yazar, Osmanlı Imparatorluğu'nda Sarraflık, s. 46-48; Eldem, "İstanbul”, s. 208, 279; Özcan, "Beşir Ağa, Moralı", s. 555-556.

60 C.ML. 650/26611; Şem'dânî-zâde, Mür'it-Tevârih, s. 55; Ahmed Vasıf Efendi, Mehâsinülâsar, c. I, s. 224; Ahmet Refik, Hicri On İkinci Astrda İstanbul Hayatı (1100-1200) (İstanbul: Enderun Kitabevi, 1988), s. 199-200, 214; Aydıner, "Osmanlı Ermenileri", s. 192195; Jamgoçyan, Les Finances de l'Empire Ottoman, s. 248-250, 484; aynı yazar, Osmanlı Imparatorluğu'nda Sarraflık, s. 182.

61 Koca Ragıb Mehmed Paşa hakkında detaylı bilgi için bkz. Mesut Aydıner, Koca Ragıb Mehmed Paşa-Hayatı ve Dönemi: 1699-1763 (doktora tezi), Mimar Sinan Güzel Sanatlar Üniversitesi Sosyal Bilimler Enstitüsü, 2005.

62 Ermenilerin Ragıb Paşa döneminde önemli mevkilere geldikleri ile ilgili bkz. Aydıner, "Osmanlı Ermenileri”, s. 184-211. 
bu yükselenlerden biri olsa gerektir. Onun payına Mehmed Paşa'nın sarrafı olmak düşmüştür. Dolayısıyla hamisinin ölümü, Kazer için de bir son olmuştur. ${ }^{63}$

David gibi İngiliz himayesinde olan Kazer, Mehmed Paşa ile çalışan tek sarraf değildir. Mehmed Paşa'nın başka sarrafları da bulunmaktadır. ${ }^{64}$ Ancak diğer sarrafları, katledilmekten bir şekilde kurtulmuşlardır. Bunu nasıl başardıkları soru işaretidir. Belki nüfuzlarını kullanarak bu işten sıyrılmışlardır. Belki de Mehmed Paşa’nın geri kalan zimmetlerini ödemek için özellikle hayatta bırakılmışlardır. Her nasıl olursa olsun, Kazer'den daha şanslı oldukları kesindir.

Mehmed Paşa’nın diğer sarrafları gibi şansı yaver gitmeyen Kazer, Pars Tuğlacı'ya göre bir komploya kurban gitmiştir. ${ }^{65}$ Ancak Tuğlacı bu komplonun detaylarını açıklamaz. Belge ve kroniklerde de bu tür bir bilgiyi teyit edecek veri yoktur. Kazer, muhtemelen zenginliğini Ragıb Mehmed Paşa sayesinde elde ettiği düşüncesi ve onun mallarını sakladığı gerekçesiyle katle uğramış olsa gerektir. Arşiv belgelerinde geçen “...sadr-ı sâbık Ragıb Mehmed Paşànın ibtidâ-i sadâretinden fevti gününe dek sarraflık ve bâzergânlĭğ hıdmetinde olan Bedros ve Kazer nâm sarrafların zimmetlerinde müteveffâ-yı mûmâ ileyhin vâfir mâlı olub ve mesfûrânın dahi medîne-i Haleb'de olan şerîklerine $e^{6 \sigma}$ vâfir mal gönderdikleri tahkîken haber verilüb emvâl-i mürsele zâhire ihrâc olunmast..." ${ }^{\prime 67}$ şeklinde satırlara yansıyan bilgiler de bu ihtimali desteklemektedir.

Şemdanizade ise Ragıb Paşa'nın sarrafları ile diğer adamlarının "yed-i rüşvet" olduklarını, her birinin "âlî saraylar ve sâhil-hâneler" bina ettiklerini ve gelirlerinin

63 C.ML. 650/26611; Şem'dânî-zâde, Mür'it-Tevârih, s. 55; Ahmed Vasıf Efendi, Mehâsinülâsar, c. I, s. 224; Ahmet Refik, İstanbul Hayatı (1100-1200), s. 199-200, 214âa; Aydıner, "Osmanlı Ermenileri", s. 194; Jamgoçyan, Les Finances de l'Empire Ottoman, s. 248-250; aynı yazar, Osmanlı Imparatorluğu’nda Sarraflık, s. 86.

64 M. Aydıner, Mehmed Paşa’nın Kazer dışında Bedros Aleksiyan ve Abraham Kuleliyan adında iki sarrafı daha olduğunu belirtmektedir. Jamgoçyan ise, Bağdasar Amira Nalbantoğlu, Bedros ve Abraham Amira Aleksanyan olmak üzere üç sarraf ismi vermektedir. Bkz. Aydıner, "Osmanlı Ermenileri”, s. 192-195; Jamgoçyan, Osmanlı Imparatorluğu’nda Sarraflık, s. 86.

65 Pars Tuğlacı, Tarih Boyunca Batı Ermenileri, c. I, (İstanbul: Pars Yayın Ticaret, 2004), s. 351. Aynı bilgiyi M. Aydıner de aktarmaktadır. Aydıner, "Osmanlı Ermenileri”, s. 194.

66 Kazer’in Halep'de ortağı olup olmadığıyla ilgili yapılan tetkikat, Kazer’in ortağı olarak düşünülen kişinin, Kazer’le isim benzerliği olan başka birinin ortağı olduğu sonucunu ortaya çıkarmıştır. Bkz. MD. 163, s. 167, hüküm no. 410.

67 C.ML. 650/26611; MD. 163, s. 117, hüküm no. 304 ve s. 167, hüküm no. 410. Ahmet Refik, İstanbul Hayatı (1100-1200), s. 199-200, 214; Şem'dânî-zâde, Mür'i't-Tevârih, s. 55; Ahmed Vasıf Efendi, Mehâsinüll-âsar, c. I, s. 224; Aydıner, “Osmanlı Ermenileri”, s. 194. 
bütün devlet adamlarına üstün geldiğini yazmaktadır. ${ }^{68}$ Ona göre bu duruma Ragıb Paşa göz yummaktadır ve sadece ona mahsus da değildir. Her türlü devlet adamı böyle kişilerle iş yapmakta ve Müslümanları da onlara muhtaç etmektedir. Dolayısıyla Şemdanizade’ye göre Kazer gibi kişilerin katledilmesi, David örneğinde olduğu gibi, devlet için faydalı bir iştir. ${ }^{69}$

Yukarıdaki örnekler dışında kaynaklarda, 1764 yılında dört Eğinli sarrafın katledildiği yazılıdır. ${ }^{70}$ Onların katlediliş öyküsü ise diğerlerinden farklılık arz etmektedir. İsimleri bilinmeyen bu dört sarraf, Eğin nakîbinin idamına sebep olduklarından dolayı kısasen hayatlarını kaybetmişlerdir. ${ }^{71}$ Rumeli Kazaskeri Mîrzâzâde Seyyid Mehmed Said Efendi, sarrafların fuzuli yere katledilmelerini istememesine rağmen "te'hirinden zarar-ı azîm ve belki fitneyi müntec olacă̆̆" düşüncesiyle, dönemin şeyhülislamı Dürrîzâde Mustafa Efendi'nin "zarar-ı âmdan, zarar-ı hâss evlâdır" fetvasıyla dört sarrafın Saray Meydanı'nda infazları gerçekleştirilmiştir. ${ }^{72}$ Sarrafların şeran katledilmeleri uygun değilken Şemdanizade, İstanbul sarraflarının ekserisinin devlet malına zarar verdiklerinden dolayı siyasete muhtaç olduklarını belirtmektedir. ${ }^{73}$ Ayrıca Şemdanizade, Rum ve Ermeni sarraf-

68 Şem’dânî-zâde, Müri't-Tevârih, s. 55; Mehâsinüll-âsar'da da benzer ifadeler vardır, Ahmed Vasıf Efendi, Mehâsinül-âsar ve Hakâiküll-ahbâr, c. I (Kahire: Bulak Matbaası, 1246), s. 224

69 Şemdanizade, Kazer'in katlini anlatırken, Tiryaki Mehmed Paşa’nın David'i katl etmesine atıf yapar ve Yeniçeri Ocağının hala benzer kişilerin elinde kaldığını belirtir. Şem'dânî-zâde, Mür'it-Tevârih, s. 56. Şem'dânî-zâde, Mür'i't-Tevârih, s. 55. M. Aydıner, Şemdanizade'nin Ragıb Paşa’yı pek sevmediğini belirtir. Ama bunun nedenini açıklamaz. Aydıner, "Osmanlı Ermenileri”, s. 194.

70 Şem’dânî-zâde, Mür'i’t-Tevârih, s. 68-69; Ahmed Vasıf Efendi, Mehâsinüll-âsar, s. 263-264.

71 “Kasaba-i Ĕ̆in Nakîbi a’yândan olup, İstanbul sarraflarının, Ermenilerinin ekseri Ĕ̆inli olmağla, sarraflar nakîbe dilgir olup, şikâyet ettirüp, hasımlarn ile mürâfa’a olunmak içün Turnacı ta'yin ettirdikden sonra, va'd-i vaid ile irsâl, Turnacı dahi vardıkda, Nakîbin üzerine kan sâbit olmă̆la, hükm-i hâkim ile Turnacı Nakîbi kısas ettikde..." Şem'dânî-zâde, Müri't-Tevârih, s. 68. Ariel Salzmann, bu dört sarrafın memura rüşvet vermekten suçlu bulunduklarını belirtmektedir. Bkz. Ariel Salzmann, Modern Devleti Yeniden Düşünmek: Osmanlı Ancien Regime’i, çev. Ayşe Özdemir (İstanbul: İletişim Yay., 2011), s. 167.

72 Şem'dânî-zâde, Müri't-Tevârih, s. 68-69.

73 "Istanbul sarraflarının ekserisi cihet-i uhrâdan katle müstehaklardır. Zirâ sâlâbet-i islâmiyenin kesr ve noksanına bâdilerdir. Yàni ricâl-i devletin küberâsı bunları mahrem ve dost ittihaz ve yed-i rüsvet ettikleri içün muhtaçlar kibâra arz-ı hâcât etmekden fâide olmaz. Lâkin sarraflar murad ettiği işi fi ile ve vücûda getürdüğünden çok kimesne kavlen ve kıyâfeten gerçi Müslümandır; lâkin fỉlen mürted hükmündedir. Zirâ işime yarar deyü Müslümanlardan ziyâde sarraflara tevâzu've ikrâm eder. Bu kâfirlerde çünki ekser devletin ricalinin hail ü akdi kabzanıza girmiş sâhib olacakları adama sâhib olup, iltiyam ve 
ların, "etıbba keferesi" ve "tercümânlar" ile birlikte hareket ederek "casus"luk yaptıklarını yazmışıtır. ${ }^{74}$ Aslında bu düşüncelerden Şemdanizade’nin sarraflara biraz ön yargılı yaklaşığını açık bir şekilde anlamak mümkündür.

Bu sarraflar haricinde, tabloda da görüldüğü üzere, 1784 yılında başka bir yeniçeri ocağı bâzergânının daha katledildiği kaynaklara yansımıştır. ${ }^{75}$ İsminin İsak olduğu anlaşılan bu bâzergân, görevini kötüye kullanmak ve zimmetine para geçirmek gibi nedenlerle önce Kudüs'e sürgünle cezalandırılır. ${ }^{76}$ Ancak daha sonra bundan vazgeçilerek Devlet tarafından Rodos'a nefyi uygun görülmüştür. İsak sürgünle kurtulacağını düşünürken, İstanbul'da fesat çıkarmak için döneceği gerekçesi ile katledilmiştir. ${ }^{77}$

Darphane sarrafı Bedros (nam-1 diğer Petraki) da 18. yüzyılda katle uğrayan sarraflardan bir diğeridir. ${ }^{78}$ Bedros'un ne zaman darphane sarrafı olduğu konusunda bir kesinlik olmamakla birlikte, 1760 'lı yıllarda bu göreve getirilmiş olma-

tevâzu'una razı olmasalar olur, amma kefere kısmına firsat giricek sair intifầindan ziyâde Müslümanları mürted idecek halâta nazar ederler ve pençelerine giriftar olanlar, ömrü âhir olunca halâs olamaz, muhâlefet eden, Nakîb gibi candan muvafakat eden dinden çıkar ve ekser kibâr sarraf yedile görülen iş fass olmaz zuंmu ile bizim sarraf yalan söylemez deyü şahâdet-i zor ederler ve nabz-ı devlete bu sebebden sarraflar fubûl-i ulâmadan ve yedi ocağın ricalinden ziyâde âşinâlardir. Harbî kefereler ile ülfetleri olmak hasebile devletin gafillerini iğfal ve tama'kârân-ı devleti itmầ ve zarar-ı azîmi cüz'î sûretinde irâe ettikleri içün bunlar nizam ve siyâsete muhtaçlardır. Şimdilik bu devr-i dînin hakkında gayretullah zuhûr eyledi." Şem'dânî-zâde, Mür'i't-Tevârih, s. 69.

74 "Ve bir tercümân kefereyi akrânından mülebbes padişah tebdil görüp, hâlini tefahhuz buyurdukda, kibâr konaklarına girüp-çıkup nakl-i kelâm ettiği ma'lum olmağla Yalı-köskü̈nde buzûr-ı hümâyunda katl olundu. Bu nakl-i kelâm husûsu yalnız tercümanlara maksûr değildir. Kefere-i etibbâ ile sarraflar dahi müsterektir. Tab'- sedîde muhtaçdır ki, fark oluna ve men' oluna. "Şem'dânî-zâde, Mür'i't-Tevârih, s. 37-38.

75 Ahmed Cevdet, Tarih-i Cevdet, c. 3 (Dersaadet: 1309), s. 84.

76 "[O]cak bâzergânı olan yahudiye taraf-ı sadr-ı 'âlîden ifâde buyuruldukda çünki bâzergân-ı merkûm beher sene bu nizamsızlıdan külli istifâde edegeldiğinden bu nizâmın imkânı olmadiğın îrâd ile geçüşdürmek dấ iyyesine düşdüğ̈̈nden bâzergânlıkdan tard ve ihrâc ile Rodos'a nefy ve ba'dehu katl olunub hesâbı rüyet olundukda üç bin kise akçe kadar ıtlâfâtı meydâna çıkmışdır.” Ahmed Cevdet, Tarih-i Cevdet, c. 3, s. 84. C.AS. 1142/50743, 50785; Kılıç, "Yeniçeri Ocağı ve Yahudiler", s. 154.

77 C.ZB. 77/3833; Ahmed Cevdet, Tarih-i Cevdet, c. 3 , s. 84; Kılıç, "Yeniçeri Ocağı ve Yahudiler", s. 154.

78 Darphane sarrafı hakkında geniş bilgi için bkz. Bölükbaşı, Darbhâne-i Âmire, s. 61-62. D. 2659/1. 
1ıdır. ${ }^{79}$ Yükselişinin ardındaki en önemli kişi ise Darphane Nazırı Sıdkı Mustafa Efendi'dir. ${ }^{80}$ Ancak yükselişinin ardındaki tek kişi Sıdkı Mustafa Efendi olmasa gerektir. Çünkü Bedros’a ait muhallefat kayıtlarında devletin çeşitli yönetim kademelerinde bulunmuş kişilerle borç-alacak ilişkisi kurduğu görülmektedir. Bu kişiler arasında Sadrazam Halil Hamid Paşa (1782-1785), ${ }^{81}$ eski Darphane Nazırı ve Mısır valiliği yapmış olan Raif İsmail Paşa ${ }^{82}$ gibi önemli simalar yer almaktadır. ${ }^{83}$

Sıdkı Mustafa Efendi üzerindeki nüfuzunu kullanarak darphane sarraflığını elde eden Bedros, 1778 yılından itibaren darphane ustabaşılığı görevini de üstlenmiştir. Uzun yıllar darphane sarraflığı yapan Bedros, 19 Nisan 1786 tarihinde katledilerek, ${ }^{84}$ kendisinin ve ailesinin malları müsadereye ${ }^{85}$ uğramıştır. Gerekçe

79 Barsoumian'ın verdiği bilgiye göre, 1752 tarihinde Dzeron Amira’nın yerine Petraki Çelebi darphane sarrafı olmuştur. H. L. Barsoumian, Amiralar Sınıfı, s. 94. Jamgoçyan da benzer bir bilgi sunmaktadır. Jamgoçyan, Osmanlı Imparatorluğu’nda Sarraflık, s. 77, 86, 182; Vasıf Tarihi'nde ise Bedros'un İstefan'ın hizmetkarı olduğu yazılıdır. Ahmed Vasıf Efendi, Mehâsinül-Âsâr ve Hakâikül-Ahbâr, haz. Mücteba İlgürel (İstanbul: İstanbul Üniversitesi Edebiyat Fakültesi Yay., 1978), s. 333. Ö. F. Bölükbaşı, Vasıf Tarihi'nde yer alan bu bilgiyi arşiv belgelerindeki verilerle birleştirerek, Bedros'un 1760'lı yıllarda İstefan'ın halefi olarak darphane sarrafı olduğunu belirtmektedir. Bölükbaşı, Darbhâne-i Âmire, s. 61. Ancak, hem 28 Nisan 1765 (7 ZA 1178) tarihli belgede ikisinin de "darbhâneli sarraf" olarak birbirlerine kefil olmaları, hem de 23 Aralık 1786 (2 RA 1201) tarihli başka bir kayıtta İstefan'ın "maktûl-i mesfûrun şerîki ve hâlen Darbhâne sarrafi” şeklinde anılması, onların bu görevi ortak yürüttüklerini açık bir şekilde göstermektedir. Bkz. C.BLD. 11/527; MAD.d. 9994, s. 284; Topkapı Sarayı Müzesi Arşivi (TSMA) E. 11117.

80 Ahmed Vasıf Efendi, Mehâsinül-Âsâr, s. 333; Bölükbaşı, Darbhâne-i Âmire, s. 61.

81 Halil Hamid Paşa ile ilgili geniş bilgi için bkz. İsmail Hakkı Uzunçarşıll, "Halil Hamid Paşa”, Türkiyat Mecmuası, V (1936), s. 213-269; Kemal Beydilli, "Halil Hamid Paşa", TDV İlâm Ansiklopedisi, 1997, XV, s. 316-318; Fikret Sarıcaoğlu, Kendi Kaleminden Bir Padişahın Portresi: Sultan I. Abdülhamid (1774-1789) (İstanbul: TATAV Yay., 2001), s. 144-152.

82 Raif İsmail Paşa hakkında bkz. Mehmed Süreyya, Sicill-i Osmanî, c. 3 (İstanbul: Tarih Vakfı Yurt Yayınları, 1996), s. 837-838.

83 Bu kişilerin listesi için bkz. MAD.d. 9718; HH.d. 14089; D.BŞM.d. 5401 vd., Jamgocyan, İsveç beratlısı olan Bedros'un III. Mustafa tarafından çok takdir edildiğini ve hatta onun Şehzade Selim’e dahi borç verdiğini belirtmektedir. Bkz. Jamgoçyan, Osmanlı Imparatorluğu'nda Sarraflik, s. 77.

84 Bölükbaşı, Darbhâne-i Âmire, s. 61; C.ML. 604/24910.

85 Bedros'un ölümünün ardından hem kendisi hem de aile ve iş ortakları müsadereye uğrayarak mallarına el konulmuştur. Bedros, ailesi ve ortaklarının müsadere edilen malları ile ilgili bkz. MAD.d. 9718, s. 370-380; MAD.d. 9742, s. 71-406; HH.d. 14089, 14090; D. 2659, 6436, 7217; D.BŞM.MHF, 12994; AE.SABH.I, 29/224 vd. 


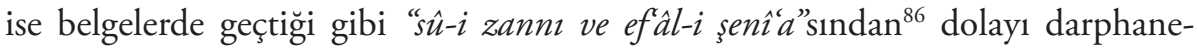
de yolsuzluk ve devlete ihanettir. ${ }^{87}$ Ancak dönemin kronikleri incelendiğinde Bedros'un katlinin farklı bir arka planı olduğu görülmektedir. Kroniklerde genellikle Eflak voyvodas ${ }^{88}$ Nikolaki Mavroyani'den ${ }^{89}$ bahsedilen kısımlarda Bedros'a değinilmekte ve Mavroyani'nin Bedros'un katline sebep olduğu belirtilmektedir. ${ }^{90}$

Nikolaki Mavroyani, 1786 yılında Eflak voyvodalığına atanmış ve dört yıl bu görevde kalmıştır. Onun kariyeri, voyvodalığa yükselen diğer Fenerli asilzadelerden farklı gelişmiştir. 1735 yılında Paros adasında dünyaya gelen Mavroyani, İstanbul'a geldikten sonra Kaptan-1 derya Cezayirli Gazi Hasan Paşa'nınn ${ }^{91}$ sarrafı Hacı Nikolaki'ye intisap etmiştir. Hacı Nikolaki sayesinde Hasan Paşa ile tanışan Mavroyani'nin kaderi hızlı bir şekilde değişmeye başlamıştır. Kariyer basamaklarına önce donanma tercümanlığında küçük bir yazıcılıkla başlayan Mavroyani, Hasan Paşa’nın itimadını kazanarak kısa süre içinde donanma tercümanlığına (1770) terfi etmiş̧ir. Gazi Hasan Paşảnın yanı sıra onunla güçlü bağları olan dönemin sadrazamı Koca Yusuf Paşa (1786-1789)'nın² da desteğini alan Mavroyani, 1786 yılında Dragozade Mihalaki Bey’in yerine Eflak voyvodalı̆̆ına atanmış-

86 MAD.d. 9742, s. 71-74.

87 C.DRB. 4/167; Ahmed Vasıf Efendi, Mehâsinüll-Âsâr, s. 333; Taylesanizâde Hâfız Abdullah Efendi Tarihi: İstanbul'un Uzun Dört Yilı (1785-1789), haz. Feridun M. Emecen (İstanbul: TATAV Yay., 2003), s. 28, 142, 143; Bölükbaşı, Darbhâne-i Âmire, s. 61; Cezar, "Osmanlı Devleti'nde Sarraflar”, s. 193; Jamgoçyan, Osmanlı Imparatorluğu'nda Sarraflı, s. 77.

88 Eflak Voyvodalığı ve 18. yüzyıldaki voyvodalar hakkında bkz. Uzunçarşılı, Osmanlı Tarihi, c. 4/2, s. 41-60; Cafer Çiftçi, "Bâb-1 Âlî̀ nin Avrupa’ya Çevrilmiş İki Gözü: Eflak ve Boğdan'da Fenerli Voyvodalar (1711-1821)”, Uluslararası İlişkiler Dergisi, 7/26 (2010), s. 27-48.

89 Nikolaki Mavroyani hakkında detaylı bilgi için bkz. Ahmed Cevdet, Tarih-i Cevdet, c. 5 (Dersaadet: 1309), s. 63-67; Ü. Filiz Bayram, Enverî Târîhi: Üçüncü Cild (Metin ve Değerlendirme) (doktora tezi), İstanbul Üniversitesi Sosyal Bilimler Enstitüsü, 2014, s. 732-735; Uzunçarşılı, Osmanlı Tarihi, c. 4/2, s. 58-60; Christoph K. Neumann, "Birey olmanın alameti olarak tüketim kalıpları? 18. yüzyıl Osmanlı meta evreninden örnek vakalar”, Tarih ve Toplum Yeni Yaklaşımlar, 8 (2009), s. 7-47; Philliou, Biography of an Empire, s. 54-56.

90 Ahmed Cavid, Hadîka-i Vekâyi', haz. Adnan Baycar (Ankara: TTK 1998), s. 132; Taylesanizâde Hâfız Abdullah Efendi Tarihi, s. 28, 142-143; Ahmed Cevdet, Tarih-i Cevdet, c. 5, s. 65; Rûzmerre, I. Abdülhamid-III. Selim Dönemi Olayları Kronolojisi, v. 19b; Bayram, Enverî Târîhi, s. 735 .

91 Cezayirli Gazi Hasan Paşa ile ilgili bkz. İsmail Hakkı Uzunçarşılı, "Cezayirli Gazi Hasan Paşaya Dair," Türkiyat Mecmuası, VII (1942), s. 2-44; Mahir Aydın, “Cezayirli Gazi Hasan Paşa," TDV İlâm Ansiklopedisi, 1993, VII, s. 501-503.

92 Koca Yusuf Paşa hakkında bkz. Uzunçarşılı, Osmanlı Tarihi, c. 4/2, s. 439-444, 454; Kemal Beydilli, "Yusuf Paşa, Koca," TDV İslâm Ansiklopedisi, 2013, XLIV, s. 23-25. 
tır. ${ }^{93}$ Aslında bu atama Hasan ve Yusuf Paşa'ların girişimiyle Mihalaki Bey’in zorla voyvodalıktan el çektirilmesi sayesinde gerçekleşmiştir. ${ }^{94}$ Sorun da muhtemelen bu noktada başlamış olmalıdır. Çünkü Mavroyani, divan tercümanı olmadan doğrudan donanma tercümanlığından voyvodalığa yükseltilmiştir. ${ }^{95}$ Dolayısıyla Mavroyani'nin bu haksız yükselişi hem eski voyvoda Mihalaki Bey ve onun destekçilerini, hem de diğer Fenerli asilzadeleri rahatsız ettiğinden Mavroyani’ye karşı bir muhalefet söz konusu olmuştur. Darphane sarrafı Bedros da Mavroyani'nin muhaliflerinden birisidir. ${ }^{96}$

Bedros, muhtemelen eski voyvoda Mihalaki Bey'le olan bağı nedeniyle Mavroyani'nin voyvoda olmasına muhalefet etmiş olmalıdır. Belki de devletin kendisine tahsis ettiği, Eflak ve Boğdan voyvodaları tarafindan verilen yıllık geliri ${ }^{97}$ kaybetme korkusu onu bu muhalefete itmiştir. Her ne sebeple muhalefet etmiş olursa olsun onun bu tavrı sarayın en güçlü iki kişisi tarafından desteklenen Mavroyani'nin oklarını üzerine çekmesine neden olmuştur. Dolayısıyla Mavroyani, Eflak voyvodası atandığı gün Cezayirli Gazi Hasan Paşa ve Koca Yusuf Paşa üzerindeki nüfuzunu kullanarak, Bedros'u katlettirterek, intikamını acı bir şekilde almıştır.

Bedros'un oğlu İstavraki (İstoraki)'nin babasından kalma malların iadesi için yazdığı arzuhaldeki bilgiler biraz duygusal olmakla birlikte, Mavroyani'nin sadece Bedros'la yetinmediğini göstermektedir. Arzuhalin içeriği şöyledir:

93 Ahmed Cevdet, Tarih-i Cevdet, c. 5, s. 63-67; Ahmed Cavid, Hadîka-i Vekâyi', s. 132-133; Taylesanizâde Hâfız Abdullah Efendi Tarihi, s. 28, 142-143; Rûzmerre, v. 46b; Bayram, Enverî Târîhi, s. 732-735; Uzunçarş1l, Osmanlı Tarihi, c. 4/2, s. 58-60; Neumann, "18. yüzyıl Osmanlı meta evreninden örnek vakalar”, s. 7-47; Philliou, Biography of an Empire, s. 54-56.

94 "Hasan Paşa kầimmakâm oldukda Eflak voyvodası Mihal tarafina ba'zı mahallerden kâğıdlar gönderüb şöyle ki: Selâmet-i nefsin làzım ise voyvodalıkdan kef-i yed edesin deyu imâ olunmağla Mihal dahi havf-ı cân ile istifâ etdikde Mavroyani Eflak voyvodalı̆̆ın tahsîl" Bkz. Ahmed Cevdet, Tarih-i Cevdet, c. 5, s. 64-65.

95 Neumann, "18. yüzyıl Osmanlı meta evreninden örnek vakalar”, s. 30.

96 Ahmed Cevdet, Tarih-i Cevdet, c. 5, s. 65.

97 "Darbhâne-i âmirem Sarrafi [...] Petraki zimmi [...] sarrâflık-ı mezkûr hıdmetiyle [...] bir yer-

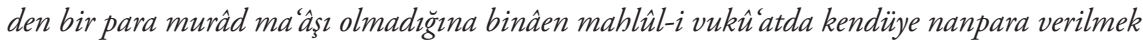
şartıyla bundan akdem bâ hat-ı hümâyun-ı şevket-makrûnumla yedine bir kit'a ustabaşılık berâtı i tâ olunmă̆la sebkat eden hıdmeti mukâbili iki yüz elli guruş Eflak voyvodalarndan ve yüz elli guruş dahi Boğdan voyvodalarından cem'an dört yüz guruş seneviye ta yîn ve beher sene voyvoda-i mûmâ ileyhümâ taraflarından ahz olunmak" C.ML. 604/24910; Cezar, "Osmanlı Devleti'nde Sarraflar”, s. 189. 
“[...] [B] undan akdem Darbhâne-i âmire sarrafı babamız Bedros emekdâr kulları katîlen hâlik olub "emvâl ve eşyâsı cânib-i mirîden zabt olundukda [...] Sultân Abdülhamid Hân [...] Hazretleri bu eytâm kullarına merhameten İstanbul'da Fener'de vâkı' menzilimiz ile Tarabya'da olan hâne-i fakîrânemizi ihsân-1 nutk-1 hümâyûn etmişiken Eflak voyvodası maktûl Mavroyani etrafa istinâdı ve ta'alluk tâmmı olduğundan zikr olunan hânelerimizi fuzûlü zabt ve bu bîkes kullarını hilesinden nâşi berâber Eflak'a getürüb ol esnâda rikâb-1 kamertâb-1 hüsrevâneye 'arzuhâl ile ifâde-i hâl eylememize mâni' olub ba'dehu Eflak'da cevâb eylediği, pâdişâh-1 âlempenâh sizleri bana esîr verdi' deyu eylemediği cevr ü cefâ kalmadığından sonra sefer-i hümâyûn vukû́unda bir akçe harcırâh vermeyüb beş nefer eytâm kullarını azâd edüb hezâr cevr ile karyelerden dilenerek âsitâneye vusûlümüzde kapu kethüdâsı ve sâbık dîvânhâne tercümânı yeğeni İstefânaki zâlim ve gaddâr hezâr gûna tahvîf ile ahvâl-i perîşânımızı ifâdeye mâni‘ olub [...]." ${ }^{\prime 8}$

Görüldüğü üzere Mavroyani'nin öfkesi sadece Bedros'u katl ettirtmekle geçmemiş, onun öfkesinden Bedros'un ailesi de payına düşeni almıştır. Ancak kendisi de dört yıl gibi çok kısa bir süre içinde aynı akıbete uğramaktan kurtulamaz. Mavroyani de kaynaklarda geçtiği şekliyle“bir nev'-i mücâzât-ı ilâhiye” olarak, hamisi Cezayirli Gazi Hasan Paşa’nın (1790) vefatının ardından Bedros’a yaptığının karşılığını bulmuştur. ${ }^{99}$ Dolayısıyla ortada sadece "devlet malına halel" gibi basit açıklamalarla geçiştirilebilecek bir katl örneği yoktur. Bedros'un katli, daha geniş bir perspektiften bakıldığında, Osmanlı siyasi hayatında sıklıkla görülen iktidarı ele geçirme mücadelelerinin açık bir sonucudur.

Bedros’un katledilişi Cezayirli Gazi Hasan Paşa ve Halil Hamid Paşa hizipleri arasında yaşanan çatışmaların bir devamı olsa gerektir. ${ }^{100}$ Bedros'un Halil Hamid Paşa ve onun ardından görevinden azl edilerek idam edilen Vezir Raif İsmail Paşa ile bağlarının bulunması, Mavroyani'nin de Cezayirli Gazi Hasan Paşa kapısından yetişerek onun desteğiyle yükselmiş olması, böyle bir ihtimali akla getirmektedir. Kemal Beydilli'nin Halil Hamid Paşa’nın katline, çıkarları zedelenen ve I.

98 C.ML. 59/2679.

99 Ahmed Cavid, Hadîka-i Vekâyí, s. 132; Ahmed Cevdet, Tarih-i Cevdet, c. 5, s. 67.

100 Halil Hamid Paşa ve Cezayirli Gazi Hasan Paşa arasındaki çatışmalar ile ilgili geniş bilgi için bkz. Ahmed Cevdet, Tarih-i Cevdet, c. 4, 247-250; Uzunçarşıllı, "Halil Hamid Paşa”, s. 246-253; aynı yazar, "Cezayirli Gazi Hasan Paşàya Dair”, s. 21-22; Sarıcaoğlu, Sultan I. Abdülhamid (1774-1789), s. 144-152; Beydilli, "Halil Hamid Paşa”, s. 317-318; Bölükbaşı, Darbhâne-i Âmire, s. 38-39. 
Abdülhamid üzerinde büyük nüfuzu bulunan Cezayirli Gazi Hasan Paşa’nın yol açtığı şeklindeki yorumu da bu ihtimali kuvvetlendirmektedir. ${ }^{101}$

Bedros'dan iki yıl sonra bu defa I. Abdülhamid'in kız kardeşi Büyük Esma Sultan'ın (1726-1788) sarrafı Sakızlı Dimitri’nin (1788) aynı akıbete uğradığı kaynaklarda görülmektedir. ${ }^{102}$ Dimitri, Esma Sultan’ın kapı çukadarı Said Ağa ve mutasarrıfı Osman Efendi ile birlikte İşkodra mutasarrıfının isyanına ve isyan sırasında Rumeli'nin zarar görmesine neden oldukları gerekçesi ile çok daha önce bu cezaya çarptırılma tehlikesi atlatmışırı. ${ }^{103}$ Ancak I. Abdülhamid, Esma Sultan'ın hatırı için bir müddet cezayı ertelemiştir. ${ }^{104}$ Aslında bu erteleme, Dimitri ve Esma Sultan arasındaki bağın ne kadar kuvvetli olduğunu göstermesi noktasında önem arz eder. Fakat Esma Sultan'ın kısa bir süre sonra ölmüş olması Dimitri’nin sevincini kursağında bırakmış gibidir. Çünkü Sultan’ın ölümünün ardından adamları soruşturmaya uğrayacaktır. Esma Sultan’ın mal varlığını ortaya çıkarmak amacıyla yapılan soruşturma sonucu Said Ağa ve Osman Efendi sürgünle cezalandırılmıştır. ${ }^{105}$ Lakin Dimitri onlar kadar şanslı değildir. Daha önce hayatını borçlu olduğu Esma Sultan bu sefer onun sonu olmuştur.

101 Beydilli, "Halil Hamid Paşa”, s. 317-318.

102 Esma Sultan hakkında bkz. Mehmed Süreyya, Sicill-i Osmanî, c. 1, s. 12; M. Çağatay Uluçay, Padişahların Kadınları ve Kızları, (Ankara: TTK 1985), s. 90-91. Sakızlı Dimitri ile ilgili daha önceki çalışmalar için bkz. Neumann, "18. yüzyıl Osmanlı meta evreninden örnek vakalar", s. 7-47; Mustak, "Death of a Banker: Dimitrios Skanavis".

103 Bu İşkodra mutasarrıfı 1785 yılında isyan eden Kara Mahmud Paşa'dır. Geniş bilgi için bkz. Uzunçarşıl1, Osmanlı Tarihi, c. 4/1, s. 615-618. "[N]ice seneden berü Devlet-i aliyye’ye hayli

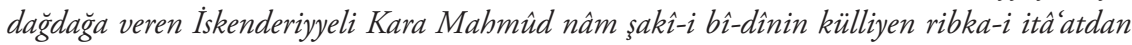
hurûcuna ve ol havâl ve belki mecmû-ı Rûmilinin bir kaç defa pâ-zede-i asâkir olmasina bunlar sebeb-i müstakille olup, etmedikleri kalmamış idi. "Çınar, Mehmed Emin Edîb Efendi, s. 53; Ahmed Cevdet, Tarih-i Cevdet, c. 4, s. 92.

104 Çınar, Mehmed Emin Edîb Efendi, s. 52-53; Ahmed Cevdet, Tarih-i Cevdet, c. 4, s. 92.

105 "[Ç]endîn müddetden berü hidmetlerinde olup sâye-i devletlerinde umûr-ı dâd u sitâd-ı âleme istîlâ ve kendi milleti beyninde şöhret-i mâl ü menâl ve nüfûz-ı kelâm ile isti lâ eden Sakızlı Dimitri nâm bâzergân ile müşârun-ileyhânın Kethudâlar Çelebi Efendi'nin Kapu-çukadarı Sa'îd der-akab furun ta bîr olunan bostancilara habsleri fermân olundu. Ve anlardan başka müsârun-ileyhânın masraf kitâbeti hizmetlerinde olup etvâr-ı nâ-becâsı âvâzesi sâmi'a-hırâş-ı sükkân-ı âlem olan müderrisînden Osmân Efendi nâm mefsedet-pî̧senin etvâr ü girdârı ma lûm-ı pâdişâh-ı enâm olmağla bâ-hatt-ı hümâyûn ismi defter-i müderrisînden hakk ve baş-bâkî kûlu habsine virilüp vakt-i istîlâsında tedârik eylediği mukâta 'âtı katla bedel üzerinden def ve su'âl ve cevâbı tekmîlden sonra cezîre-i () nefy ü iclâ olundu. "Çınar, Mehmed Emin Edî̀ Efendi, s. 52; Ahmed Cevdet, Edib Tarihi'nden alıntı yaparak benzer bir anlatım yapar. Bkz. Ahmed Cevdet, Tarih-i Cevdet, c. 4, s. 91. Daha sonra Said Ağa Soğucak’a, Osman Efendi ise Bozca 
Esma Sultan ve Dimitri arasındaki bu kuvvetli bağ, acaba nasıl kurulmuştur? Doğrudan kendisi mi Esma Sultan’a intisap etmiştir? Yoksa Esma Sultan'ın kethüdası Çelebi Efendi'nin ya da mutasarrıfı ve kapı çukadarı aracılı̆̆ı $\mathrm{m} ı$ bu bağın oluşmasında etkilidir? Bu konuda kesin bir şey söylemek mümkün değildir. Ancak kesin olan tek şey, Esma Sultan’ın, Dimitri'nin yükselişinde başat bir rol oynadığıdır.

Dimitri'nin bağlantıda olduğu tek kişi Esma Sultan değildir. III. Mustafánın kızı Beyhan Sultan (1765-1824) ve I. Abdülhamid'in kızı Emine Sultan (17881791) gibi diğer hanedan mensupları; Melek Mehmed Paşa, Nasuh Paşa, Hatmanzade Hüseyin Efendi, Aydın Muhassılı Cihanzade Hüseyin Bey, Mora Valisi Ahmed Paşa, Ohrili İsmail Paşa, Atina Voyvodası Mustafa Bey gibi merkez ve taşranın yönetici elitleri; sarraflar, bâzergânlar gibi toplumun farklı kesimlerinden önemli kişiler, Dimitri'nin müşteri portföyünde yer almaktadır. ${ }^{106} \mathrm{Bu}$ kadar önemli kişinin bulunduğu portföyü Dimitri'nin nasıl oluşturduğu soru işaretidir. C. Neumann, Dimitri'nin çevre ve prestij kazanmasında eşi İzmiranda (Ezmeralda)'nın rolünün büyük olduğuna vurgu yapar. Ona göre taşralı bir aileden gelmiş olan Dimitri, Fenerli Rum muhitinden kız alarak hem işini hem de ufkunu genişletmiştir. ${ }^{107}$ Eşinin rolü yadsınamaz ancak bir sarrafın taşradan gelerek bu kadar üst düzey kişinin güvenini kazanarak onlarla iş yapması tek başına eşinin oynadığı rolle açıklanamaz. Dimitri’nin doğru zamanda doğru adımlar attığı kesindir. Bu adımlardan biri de hiç kuşkusuz bir şekilde doğrudan ya da dolaylı olarak Esma Sultan'la bağlantı kurmuş olmasıdır. Bu da muhtemelen Esma Sultan'ın Sakız'da olan mukataalarından ötürü gerçekleşmiş olsa gerektir. Dolayısıyla padişahın kız kardeşi olması hasebiyle büyük nüfuz sahibi olan Esma Sultan'ın himayesine girmiş olan Dimitri’nin, onun sayesinde İstanbul çevrelerinde tanınma firsatı yakalayarak bu geniş portföyü oluşturmuş olabileceği ihtimali akla daha yatkın gelmektedir.

Esma Sultan haricinde portföyünde başka hanım sultanlar ve paşalar olmasına rağmen Dimitri'nin idam edilmiş olması, daha önceki örneklerde de belirttiğimiz gibi mal varlığını bağlantıda olduğu kişi sayesinde elde ettiği düşüncesinden dolayı olsa gerektir. Bu açıdan Dimitri'ye isnat edilen suçların başında "devlet

Ada’ya sürgün edilmiştir. Osman Efendi yolda deryaya düşerek hayatını kaybetmiştir. Bkz. Taylesanizâde Hâfiz Abdullah Efendi Tarihi, s. 43, 300.

106 Bu kişilerin detaylı listesi için bkz. MAD.d. 9719, s. 75-149; C.ML. 570/23336; D.BŞM. MHF. 85/55.

107 Neumann, “18. yüzyıl Osmanlı meta evreninden örnek vakalar”, s. 26. 
malına zarar" gelmektedir. Edib Tarihi'nde Dimitri'nin sadece bâzergânlıkla yetinmediği, Esma Sultan'ın himayesinde olmasından aldığı güçle Sakız adası halkını kendi "réâyâsı menzilesinde" gördüğü, Aydın ve Mora caniblerinin işleriyle kendi ilgilendiği, Osman Efendi ve Said Ağa ile birlikte Esma Sultan adına etmedikleri zulm kalmadığı belirtilmektedir. ${ }^{108}$ Dimitri, yapılan suçlamalarda yalnız değildir. Esma Sultan'ın adamları Said Ağa ve Osman Efendi ile ortak olarak itham edilir. Yukarıda da değindiğimiz gibi aynı ekip, İşkodra mutasarrıfının isyanına ve bu isyan sırasında Rumeli'nin zarar görmesine de neden olmakla suçlanırlar. ${ }^{109}$ Ahmed Cevdet kaynak olarak kullandığı Edip Tarihi’nde yer alan bu suçlamaları biraz şüpheli bulmaktadır. Cevdet, Dimitri ve diğerlerinin Rumeli işlerine, Esma Sultan'ın bölgede çok sayıda mukataasının olmasından dolayı müdahale etmiş olabileceklerini belirtir. Ona göre eğer Edib Efendi'nin bu iddaları doğru ise nasıl olur da böyle bir kaç asiye "tahrîb-i bilâd" ve "zzrâr-ı "ibâd" edebilecek şekilde yüz verilip sonra cezalandırılmaları istenir. Belirtilen bu iddia doğru değilse Dimitri ve diğerlerinin malları için zulme uğramaları büyük bir insafsıllıktır. Dolayısıyla Cevdet, böyle bir olayı, Abdülmecid döneminde olan adalet ve emniyeti bildirmek ve herkesi onun himayesine mecbur etmek gibi büyük bir faydası olmasa kaleme almaktan "hayâ" edeceği yorumunda bulunur. ${ }^{10}$

I. Abdülhamid ve III. Selim dönemi olaylarını kronolojik olarak anla$\tan$ Rûzmerre'de ${ }^{111}$ ise farklı bir suçlama söz konusudur. Dimitri'nin Sultan III.

108 “[M]esfûr Dimitri yalnız bâzergânlık ile kanâ'at etmeyüb iltizâmât-ı mukâta 'ât ve sầir vechle umûr-ı külliyeye karışup sâye-i himâye-i müşârun-ileyhâda metâ'- nâsı kendi endâzesiyle ölçer ve biçer idi. Ve bâ-husûs Sakız adası umûmen kendünün réâyâsı menzilesinde olup kimin zehresi var idi ki réyine muhâlefet edebile. Ve Aydın ve Mora câniblerinin ekser umûru kendi yediyle görülüp taraf-ı hilâfinda bulunan kendüsini diyâr-ı âherde görürdü. Ve Hakku'l-insâfş̧öle idi ki mesfûr Dimitri ile bâlâda zikr olunan Osmân Efendi ve Kapu-çukadarı Sa id'in etmedikleri zulm ü sitem kalmayup fukarâ ve zu'afâ şer ü şürûrlarından ekserîâh ü enîn ederek terk-i evtân edüp havf-ı cânlarından pâdişâh-ı âleme hâllerin ifâdeden âciz ve mukâvemetden me’yûs idiler. Merhûme-i müşârun-ileyhâyı dâimâ âlet-i revâc-ı zulm ederek "sultân efendimizin emridir" deyu hâşâ ifk u bühtân edüp kendüleri nâsı müsâdere ve harâb etdiklerinden. "Çınar, Mehmed Emin Edîb Efendi, s. 52-53. Benzer bir anlatım için bkz. Ahmed Cevdet, Tarih-i Cevdet, c. 4, s. 91-92.

109 Çınar, Mehmed Emin Edîb Efendi, s. 53; Ahmed Cevdet, Tarih-i Cevdet, c. 4, s. 92.

110 Ahmed Cevdet, Tarih-i Cevdet, c. 4, s. 92.

111 Rîzmerre, I. Abdülhamid ve III. Selim dönemi olaylarını kronolojik olarak anlatan 49 varaklık bir yazmadır. 9 Zi'l-ka'de sene 1187 (22 Ocak 1774) ve 18 Rebi'ü'l-ahir sene 1205 (25 Aralık 1790) tarihleri arasındaki olayları içermektedir. Türk Tarih Kurumu Kütüphanesi, Yazma: Y/1001. 
Mustafa döneminde Ruslarla birlik olduğu ve kendisine Sakız krallığı payesi verdirdiği yazılıdır. ${ }^{12}$ Dolayısıyla Dimitri, "devlete ihanetle" de suçlanmaktadır.

Bu suçlamalar sadece Dimitri'nin sonunu getirmemiştir. Onunla birlikte ailesi de büyük bir yıkıma uğrar. Neredeyse tüm ailesinin mal varlığına el konulduğu gibi bazı akrabalarının da firarı söz konusudur. ${ }^{113}$ Ancak en büyük zararı kardeşi Cani görmüştür. Şöyle ki diğer sarraf katllerinde rastlanılmamasına rağmen "hẩin-i din-i devlet" olan Sakızlı Dimitri'nin kardeşi olması ve bunun yanı sıra reayaya zarar vermesinden dolayı suçlanarak Cani de katledilmiştir. ${ }^{114}$

Son örneğimizi ise 1790 yılında katl olunan Mısır sarrafı Artin oluşturmaktadır. ${ }^{115}$ Artin'in katledilmesinin gerekçesi, Mısır'ın Memlük beylerinden olan İbrahim ve Murad Beylerin isyanına karışmış olmasıdır. ${ }^{116}$ İsyanın temeli Aleviyye ve Muhammediyye hizipleri arasında Mısır'ın iktisadi kaynaklarını kontrol etmek amacıyla yaşanan mücadelelere dayanmaktadır. 1779 yılından itibaren Muhammediyye grubunun üstün gelmesiyle birlikte, bu hizipten olan İbrahim ve Murad Beyler, aralarında anlaşmazlıklar çıkmasına rağmen, Mısır’n yönetimini ortak yürütmeye başlamışlardır. Kontrolü ele geçiren beyler devlete karşı yükümlülüklerini yerine getirmeyerek Mısır'ın Osmanlı devleti ile olan bağlarını koparmaya çalışmışlardır. Bu bağlamda Mısır’n bağımsızlığına yardımcı olmaları

112 “[...] [M]esfur Dimitri”nin evraklar yoklanub içinde Moskov kralının mührüyle bir kağıd bulunub tercüme eylediklerinde mefhumunda Sakız krallı̆̆ın kendüsüne ittihad etdirdiğ mesmu'- hümayun olmağla mah-ı Zi'l-ka'denin on dördüncü cuma ertesi günü saray meydanında mesfur Dimitri katl olunub ve üzerine vaz' olunan yafta bu minval üzere tahrir olunmus ki suret-i yafta cennet-mekan firdevs-aşiyan Sultan Mustafa Han zamanında Moskov kralliyla ittihad edüb kendüsüne Sakız krallĭgı payesi verdiren hain-i din-i devlet olan Dimitrinin sermaktû'dur." Rûzmerre, v. 27b. Taylesanizâde de Rûzmerre'ye atıf yaparak aynı bilgiyi aktarır. Taylesanizâde Hâfiz Abdullah Efendi Tarihi..., s. 300. Jamgocyan, Skanaviler gibi Rum sarrafların katledilmelerine Ruslarla yapılan savaşlar veya Yunan bağımsızlık savaşı bağlamında bakılmasını belirtmektedir. Bkz. Jamgoçyan, Osmanlı Imparatorluğu’nda Sarraflık, s. 88.

113 Dimitri'nin ve Cani'nin katli ile birlikte, uzak yakın bütün ailenin mallarına el konulmuştur. Bu malların bir kısmı daha sonra sahiplerine iade edilecektir. Bkz. MAD.d. 9719, s. 75-149; D.BŞM.MHF. 80/14, 80/20, 80/21, 80/48, 85/55; C.ML. 226/9413, 266/10887, 266/10890, 295/12045; Neumann, "18. yüzyıl Osmanlı meta evreninden örnek vakalar", s. 22-26. Örneğin Dimitri’nin damadı Yakomu, kardeşinin oğlu ve aynı zamanda ortağı Kostantin firar etmişlerdir. Bkz. MAD.d. 9743, s. 8; AE.SSLM.III. 390/22570.

114 Rûzmerre, v. 28a-b; Taylesanizâde Hâfiz Abdullah Efendi Tarihi, s. 310.

115 Ahmed Cavid, Hadîka-i Vekâyi, s. 58; Jamgoçyan, Osmanlı İmparatorluğu’nda Sarraflık, s. 182.

116 Ahmed Cavid, Hadîka-i Vekâyi, s. 47; HAT. 273/16089; HAT. 192/9368. 
için 1783 yllında İskenderiye, Dimyat ve Reşid'de askeri üsler verilmesi karşılı̆̆ında Rusya’nın desteğine başvurmuş olan İbrahim ve Murad Beyler, 1785 yllında da Fransa ile bir ticaret anlaşması imzalamışlardır. İbrahim ve Murad Beylerin bu girişimlerini cezalandırmak amacıyla devlet Cezayirli Gazi Hasan Paşàyı bölgeye göndermiştir. Asi beylerin kontrol altına alınmasıyla problem kısa bir süre çözüme kavuşmuş gibi gözükse de Mısır’n bu durumu Fransa'nın bölgeyi işgaline kadar sürmüştür. ${ }^{117}$ İbrahim ve Murad Beylerin isyanı, Mısır'daki haneler arası çekişmeler bazında bakıldığında bir iç sorun özelliği gösteriyor olsa da aslında Fransa ile yapılan ticaret anlaşması ve Rusya faktörü de göz önüne alındığında uluslararası niteliği olan farklı bir boyutu da bulunmaktadır. Hadîka-i Vekâyi adlı eserinde Ahmed Cavid, Mısır sarrafı Artin'in de dahil olduğu bu süreçle ilgili şu bilgileri vermektedir:

"Sadr-ı sâbık merhûm Gazi Hasan Paşa Mısır'in nizâmına muvaffak olub, İbrahim Bey ile Murad Bey avaneleriyle derûn-ı Misir'dan ihrâc ve alâ-tarîkür-rehn iki bey ile kâşif atabe-i ulyâya götürmüşdü. Tek durmayup, usâta kağıt gönderdikleri ecilden mâlları müsâdere ve kendüleri Limni Adasina nefy olmuşdu. Ba'dehû Cülûs-ı Hümâyûn'da itlâk olunup, cürümleri afv olmuş iken yine tarafgirlik eyledikleri ecilden tekrâr Limni'ye nefy olunup ve andan bi't-takrîb firâr edüp, usâta mülhak olmağla Âsitâne-i Aliyye'de erâcif çoğalup, beyler itlâk olmuş kemâfi'l-evvel Misir'a girecek imiş, havâdisi zuhûr ve nizâm-ı Mısır'a mémûr olanların nüfûzuna halel vereceği zâhir olup, tecessüs olundukda bu havâdisler Artin nâm sarrâfdan neş'et eylediği zâhir oldukdan sonra gönderdiği mektûblar dahi ahz olundukdan sonra habs olunmuş idi." 118

Metinde de geçtiği şekilde Artin, İbrahim ve Murad Beylerin isyanı sırasında bazı yazışmalar yapmış gözükmektedir. Muhtemelen Artin bu yazışmalarla, hamileri İbrahim ve Murad Beylerin Ruslar ile olan diyaloğuna aracılık etmiş olmalıdır. Devlet için risk oluşturan bu konunun tetkik edilmesi amacıyla Artin önce haps edilir. ${ }^{119}$ Yapılan soruşturmada Artin, "dîn ü devlet-i 'aliyyenin bẩini" olma-

117 İbrahim ve Murad Beylerin isyanı ile ilgili geniş bilgi için bkz. Uzunçarşılı, Osmanlı Tarihi, c. 4/1, s. 509-518, 603-605; Necmi Ülker, "XVIII. Yüzyılda Misır ve Cezayirli Hasan Paşa'nın Mısır Seferi”, Tarih Incelemeleri Dergisi, 9/1 (1994), s. 1-30; Selda Güner, "Mısır’n Son Memlük Beyleri (1801-1806)," Cumburiyet Tarihi Araştırmaları Dergisi, 22 (2015), s. 231-235.

118 Ahmed Cavid, Hadîka-i Vekâyi, s. 47.

119 "Sûret-i Hatt-ı Hümâŷ̂n: Kầimmakâm paşa, firâri beyler içün habisde olan sarrâfin Mısır'a yazdiğı kağıtları tarafina gönderdim. Mutâla'a edesin bu kâğıtları yazan kâfirin elinden çok is 
dığını, eğer hıyanet edip bu tür şeyler yazmış olsa Türkî ibare yerine Rumî ibare kullanmasının daha uygun olacağını belirterek suçlamaları inkar eder. ${ }^{120}$ Ancak daha sonra yapılan baskılara dayanamayarak kağıtlardaki mührün kendisine ait olduğunu itiraf eden Artin, ibret-i âlem için katledilir. ${ }^{121}$ Görüldüğü üzere diğer örneklerde de rastlanıldığı gibi Artin’in katledilmesinin temel gerekçesi de devlete ihanettir. Bu kişilerin gerçekten devlete ihanet edip etmediği tartışlabilir. Ancak bunlar, yabancı devletlerin Osmanlı toprakları üzerindeki politikaları ve 18. yüzyılın ikinci yarısındaki uzun süren savaşlar (özellikle de Rus politikaları ve Rusya ile yapılan savaşlar) bağlamında düşünüldüğünde anlam ifade etmektedir.

\section{Sonuç}

Yazıldığı dönemle ilgili önemli bilgiler sunan kronikler ister devlet eliyle yazdırılmış olsun ister olmasın belli bir algı yaratmak amacıyla belli bir kurgu etrafında şekillenmiştir. Bu kaynakların güvenilirlikleri için yazarlarının kimliklerinden niçin kaleme alındıklarına, dönemin siyasal ve toplumsal olaylarını nasıl algıladıklarından ne tür bir okuyucu kitlesine hitaben yazıldıklarına kadar pek çok etkenin dikkate alınması gerekmektedir. Öte yandan Cornell Fleischer'in belirttiği gibi bu kaynaklar, arşiv belgelerini dolduran kuru, kısa ve kopuk kayıtlara düşünsel tutarlılık katmaktadırlar. ${ }^{122} \mathrm{Bu}$ bağlamda sarrafların katli ile ilgili kıt bilgiler sunan arşiv belgelerinden ziyade dönemin kroniklerinde yer alan verilerden hareketle kaleme alınan bu makalede sonuç olarak şunları belirtebiliriz: Arşiv belgelerinde daha çok sarrafların yolsuzluk ve ihanet gerekçesiyle "s $\hat{u}-i$ zannı ve ef âl-i şenî‘ $a$ "larından dolayı katle uğradıklarına vurgu yapılmaktadır. Bu açıdan sadece belgelerin gözünden bakıldığında 18. yüzyılda yaşanan sarraf katllerinin

gelür. Bu tamâm devlet câsusıdır. Bu tarafda bu işleri kim söylemişdir ve bunların ıtlâkını kimlerin yediyle itdirecek imiş kendünden hakîkatini haber alsun doğrusunu isterim bu kağıtlar kâfirin olduğu sûretde gayrilerine ibret içün katl olunmak lâzımdır söyledikden sonra tertîb-i cezâ olunmak içün taraf-ı hümâyûnuma 'arz edesin deyü emr olundu. "HAT. 192/9368; HAT. 273/16089; Ahmed Cavid, Hadîka-i Vekâyi', s. 47.

120 “[...] [D]în-i devlet-i 'aliyyenin hầini değilim ferzâ hryânet edüb bu vechile şey yazmak lâzım gelse niçün Türkî 'ibâre ile yazayım Rumî 'ibâre ile yazub umûr-ı sâirem içün Mısır'a gönderdiğim ademime verüb irsâl ederdim ve dâimen bana kitâbet eden adem Elçihaninın yanındadır mektûbların yazusu anın olmadiğından başka [...] her birini başka adem yazmış deyu bi'l-külliye inkâr ve irkilmeden kavî kavî bu vechile cevâblar verir [...]. "HAT. 273/16089.

121 Ahmed Cavid, Hadîka-i Vekâyi, s. 58.

122 Cornell H. Fleischer, Tarihçi Mustafa Âli: Bir Osmanlı Aydın ve Bürokratı, çev. Ayla Ortaç (İstanbul: Tarih Vakfi Yurt Yay., 2013), s. 3. 
temelde "devlet malına halel"den kaynaklanmış olduğu belirtilebilir. Aslında bu, benzer diğer katl örneklerinde de görülebilen yaygın bir gerekçedir. Dolayısıyla arşiv belgelerinin birer resmi evrak olduğu düşünüldüğünde bu tür yaygın kalıpların kullanılması çok olağandır. Bu noktada dönemin kronikleri de arşiv belgeleriyle örtüşmektedir. Ancak yukarıda da görüldüğü gibi, satır aralarında yer alan anekdotlar, sarrafların kurmuş oldukları ilişki ağları çerçevesinde kendilerinin ya da bağlantıda oldukları kişilerin çıkarları uğruna da katledildiklerini açıkça gözler önüne sermektedir. Bunda, devletle iş yapıyor olmalarının getirdiği riskin yanı sıra, bulundukları konum gereği, hayatlarının, bağlantıda oldukları üst düzey elitlerin kaderlerine bağlı oluşu da etkilidir. Aynı zamanda kendi iç çekişmelerini de buna eklemek gerekir. Bütün bunlar birlikte değerlendirildiğinde 18. yüzyılda sarrafların devlet malına zararın ötesinde, dönemin konjonktürü gereği, iktidarı ele geçirme ya da ekonomik artığa el koyma amacıyla yaşanan hizipler arası mücadelelere de kurban gittikleri, belirgin bir şekilde kendiliğinden ortaya çıkmaktadır.

18. Yüzynlda Sarraf Katlleri: "Devlet Malına Halel"in mi, Hizipleşmenin mi Kurbanlart?

Öz @ Bu makale 18. yüzyılda katle uğramış bazı sarrafları konu edinmektedir. Böyle bir konuyu seçmemizdeki amaç, dönemin konjonktürü göz önüne alındığında yaşanan sarraf katlleri sadece "devlet malına halel"den mi kaynaklanıyordu? Yoksa sarraflar "hizipleşmenin” kurbanları mıdı? sorusuna cevap bulmaktır. Dönem olarak 18. yüzyıla odaklanılmasının nedeni merkez ve taşra elitleri arasında yaşanan ekonomik artığa el koyma mücadelelerinin yoğunlaştığı bir yüzyıl olması ve aynı zamanda bu yüzyılın sarrafların "altın çă̆ ı olmasıdır.

Anahtar kelimeler: Sarraflar, sarraf katlleri, devlet malı, 18. yüzyıl, hizipleşme

\section{Kaynakça}

\section{Arşiv Belgeleri}

Rûzmerre [I. Abdülhamid - III. Selim Dönemi Olayları Kronolojisi], Türk Tarih Kurumu Kütüphanesi, Yazma: Y/1001.

Başbakanlık Osmanlı Arşivi (BOA), AE.SABH.I. 29/224.

BOA, AE.SSLM.III. 390/22570. 
BOA, C.AS. 42/1917, 1142/50743, 1142/50785.

BOA, C.BLD. $11 / 527$.

BOA, C.DH. 166/8296.

BOA, C.DRB. 4/167.

BOA, C.ML. 226/9413, 266/10887, 266/10890, 295/12045, 176/7485, 570/23336, 59/2679, 604/24910, 46/2104, 529/21693, 37/1698, 650/26611, 45/2084, 468/19037.

BOA, C.MTZ. 13/615.

BOA, C.ZB. 77/3833.

BOA, D. 2659/1, 6436, 7217, 2411/57, 2411/58, 2217.

BOA, D.BŞM. 6886/92, 6900/106.

BOA, D.BŞM.d. 5401.

BOA, D.BŞM.MHF. 80/14, 80/20, 80/21, 80/48, 85/55, 81/15, 81/17, 82/13, 83/8, 87/118, 90/80, 92/56, 12994, 41/39, 41/40, 41/41, 41/43, 41/44, 41/46, 41/66, 42/30.

BOA, D.BŞM.MHF.d. 12602, 12605, 13698.

BOA, D.BŞM.ZMT.d. 13802, 13805, 13807, 13813, 13915, 13835, 13845.

BOA, HAT. 13/485, 13/495, 13/497, 14/580, 15/623, 15/667, 121/4946, 177/7813, 193/9442, 193/9456, 210/11343, 214/11738, 265/15393, 1382/54661, 1383/54685, 1383/54686, 1385/54895, 1390/55390, 15/623, 192/9368, 273/16089, 273/16035, 213/11657.

BOA, HH.d. 14089, 14090.

BOA, KK.d. 2447.

BOA, MAD.d. 9742, s. 71-405, 9743, s. 8, 9719, s. 75-149, 9718, s. 370-380, 10354, s. 440-507, 8253, 9759, 9994, s. 284.

BOA, MD. 163, s. 117, hüküm no. 304; s. 167, hüküm no. 410.

Topkapı Sarayı Müzesi Arşivi (TSMA) E. 11117.

\section{Diğer Kaynaklar}

Afyoncu, Erhan: "Sokullu Mehmed Paşa”, TDV İslâm Ansiklopedisi, XXXVII (İstanbul 2009), s. 354-357.

Ahmed Cavid: Hadîka-i Vekâyi‘, haz. Adnan Baycar, Ankara: TTK 1998.

Ahmed Cevdet: Tarih-i Cevdet, c. 3, 4, 5, Dersaadet: 1309.

Ahmed Vâsıf Efendi: Mehâsinül-âsar ve Hakâikül-ahbâr, c. I, Kahire: Bulak Matbaası 1246.

: Mehâsinül-Âsâr ve Hakâikül-Ahbâr, haz. Mücteba İlgürel, İstanbul: İstanbul Üniversitesi Edebiyat Fakültesi Yay. 1978. 
Ahmet Refik: Hicri On İkinci Astrda İstanbul Hayatı (1100-1200), İstanbul: Enderun Kitabevi 1988.

Akyıldız, Ali: "Sarraflık: Osmanlı Dönemi”, TDV İslâm Ansiklopedisi, XXXVI (İstanbul 2009), s. 163-165.

Arıkan, Zeki: "Eğin Kasabası'nın Tarihsel Gelişimi”, OTAM, 12 (Ankara 2001), s. 1-64.

Aydın, Mahir: "Cezayirli Gazi Hasan Paşa”, TDV İslâm Ansiklopedisi, VII (İstanbul 1993), s. $501-503$.

Aydıner, Mesut: "XVIII. Yüzyılın İkinci Yarısında Osmanlı Ermenileri ve Bazı Önemli Sîmâlar”, Hoşgörü Toplumunda Ermeniler, c. III, haz. Metin Hülagü vd., Kayseri: Erciyes Üniversitesi Yay. 2007, s. 175-217.

: Koca Ragıb Mehmed Paşa: Hayatı ve Dönemi (1699-1763), (Yayımlanmamış Doktora Tezi) İstanbul: Mimar Sinan Güzel Sanatlar Üniversitesi Sosyal Bilimler Enstitüsü, 2005.

Barsoumian, Hagop L.: İstanbul'un Ermeni Amiralar Sınıf, İstanbul: Aras Yay. 2013.

Bayram, Ü. Filiz: Enverî Târîhi: Ü̧̧üncü Cild (Metin ve Değerlendirme), (Yayımlanmamış Doktora Tezi) İstanbul: İstanbul Üniversitesi Sosyal Bilimler Enstitüsü, 2014.

Belasel, Yusuf: Osmanlı ve Türk Yahudileri, İstanbul: Gözlem Gazetecilik Basın ve Yayın A.Ş. 2004.

Beydilli, Kemal: "Yusuf Paşa, Koca", TDV İslâm Ansiklopedisi, XLIV (İstanbul 2013), s. 23-25.

: "Halil Hamid Paşa”, TDV İlâm Ansiklopedisi, XV (İstanbul 1997), s. 316-318.

Bozkurt, Gülnihal: Gayrimüslim Osmanlı Vatandaşlarının Hukuki Durumu (1839-1914), Ankara: TTK 1996.

Bozkurt, Nebi: "Sarraflık”, TDV İslâm Ansiklopedisi, XXXVI (İstanbul 2009), s. 162-163. Bölükbaşı, Ömerül Faruk: “İstanbul Sarrafları (1691-1835)”, Türk Kültürü İncelemeleri Dergisi, 30 (İstanbul 2014), s. 19-96.

: 18. Yüzyılın İkinci Yarısında Darbhâne-i Âmire, İstanbul: Bilgi Üniversitesi Yay. 2013.

Cezar, Yavuz: “18. ve 19. Yüzyılda Osmanlı Devleti'nde Sarraflar”, Gülten Kazgan’a Armă̆an: Türkiye Ekonomisi, haz. Hilal Akgül ve Fahri Aral, İstanbul: Bilgi Üniversitesi Yay. 2004, s. 179-207.

: "The Role of the Sarrafs in the Ottoman Finance and Economy in the Eighteenth and Nineteenth Centuries", Frontiers of the Ottoman Studies, vol. I, ed. Colin Imber ve Keiko Kiyotaki, London: I. B. Tauris 2005, s. 61-76.

Çiftçi, Cafer: “Bâb-1 Âlî̀nin Avrupa’ya Çevrilmiş İki Gözü: Eflak ve Boğdan'da Fenerli Voyvodalar (1711-1821)”, Uluslararası İlişkiler Dergisi, 7/26 (Ankara 2010), s. 27-48. 
Çınar, Ali Osman: Mehmed Emin Edîb Efendi'nin Hayatı ve Târîh'i, (Yayımlanmamış Doktora Tezi) İstanbul: Marmara Üniversitesi Sosyal Bilimler Enstitüsü, 1999.

Demir, Bünyamin: XIX. Yüzyılda Tarihi Yarımada Hanlarının Ekonomik Yönü, (Yayımlanmamış Doktora Tezi) İstanbul: Marmara Üniversitesi Sosyal Bilimler Enstitüsü, 2010.

Eldem, Edhem: "İstanbul: İmparatorluk Payitahtından Periferileşmiş Bir Başkente”, Doğu ile Batı Arasında Osmanlı Kenti: Halep, İzmir ve İstanbul, çev. Sermet Yalçın, İstanbul: Türkiye İş Bankası Kültür Yay. 2012, s. 165-247.

Emecen, Feridun: "Başbâki kulu”, TDV İslâm Ansiklopedisi, V (İstanbul 1992), s. 126-127. . : "Osmanlılarda Mali Kontrol Müessesesi Olarak Başbâki Kulluğu”, Feridun Emecen, Osmanlı Klasik Çăğında Hanedan Devlet ve Toplum, İstanbul: Timaş Yay. 2011, s. 218250 .

Encyclopaedia Judaica, XXI (New York 2007).

Ercan, Yavuz: Osmanlı Yönetiminde Gayrimüslimler, Ankara: Turhan Kitabevi 2001.

Faroqhi, Suraiya: “Krizler ve Değişim (1590-1699)”, Osmanl İmparatorlü̆u’nun Ekonomik ve Sosyal Tarihi (1600-1914), c. II, ed. Halil İnalcık ve Donald Quataert, çev. Ayşe Berktay, Süphan Andıç, Serdar Alper, İstanbul: Eren Yay. 2006, s. 543-757.

Findley, Carter V.: Osmanlı İmparatorluğu’nda Bürokratik Reform: Babıâli (1789-1922), çev. Ercan Ertürk, İstanbul: Tarih Vakfı Yurt Yayınları 2014.

Fleischer, Cornell H.: Tarihçi Mustafa Âli: Bir Osmanlı Aydın ve Bürokratı, çev. Ayla Ortaç, İstanbul: Tarih Vakf1 Yurt Yay. 2013.

Güner, Selda: “Mısır'ın Son Memlük Beyleri (1801-1806), Cumburiyet Tarihi Araştırmaları Dergisi, 22 (Ankara 2015), s. 227-266.

Hathaway, Jane: Osmanlı Sarayı’nın En Ünlü Harem Ağası: Hacı Beşir Ağa, çev. Hazal Yalın, İstanbul: Kitap Yayınevi 2104.

Jamgoçyan, Onnik: Les Finances de l'Empire Ottoman et les Financiers de Constantinople (1732-1853), (Yayımlanmamış Doktora Tezi) Sorbonne 1988.

: Osmanl Imparatorluğu'nda Sarraflık: Rumlar, Museviler, Frenkler, Ermeniler (16501850), çev. Erol Üyepazarcı, İstanbul: Yapı Kredi Yay. 2017.

Kafadar, Cemal: "Yeniçeriler ve Osmanlı Döneminde İstanbul'un Ayaktakımı: Yok Yere mi Asiydiler?", Osmanl Dünyasında Kimlik ve Kimlik Oluşumu: Norman Itzkowitz Armă̆anı, ed. Baki Tezcan ve Karl K. Barbir, çev. Zeynep Nevin Yelçe, İstanbul: Bilgi Üniversitesi Yay. 2012, s. 135-161.

Kaya, Süleyman: XVIII. Yüzyıl Osmanlı Toplumunda Kredi, (Yayımlanmamış Yüksek Lisans Tezi) İstanbul: Marmara Üniversitesi Sosyal Bilimler Enstitüsü, 2003.

Kenanoğlu, M. Macit: Osmanlı Millet Sistemi: Mit ve Gerçek, İstanbul: Klasik Yay. 2004.

Kılıç, Musa: "Yeniçeri Ocağı ve Yahudiler Arasındaki İlişkiye Dair Bazı Tespitler”, Akademik Incelemeler Dergisi, 10/2 (Sakarya 2015), s. 153-156. 
Koyuncu, Nuran: "Osmanlı Devleti'nde Sarrafların Mültezimlere Kefilliği”, İø̈nü Üniversitesi Hukuk Fakültesi Dergisi, 5/1 (Malatya 2014), s. 295-326.

Külekçi, Cahit: "Ermeni Kimliğinin Dönüşüm Süreci ve Amira Sınıfının Oluşumu”, Hikmet Yurdu, 6/12 (Malatya 2013), s. 101-117.

Mehmed Süreyya: Sicill-i Osmanî, 6 cilt, haz. Nuri Akbayar, İstanbul: Tarih Vakfı Yurt Yay. 1996.

Mumcu, Ahmet: Osmanlı Devleti’nde Siyaseten Katl, Ankara: Phoenix Yayınevi 2007.

Mustak, Aykut: "Death of a Banker: Dimitrios Skanavis, d. 1788", Debt and Dependence: Eight Annual Graduate History Symposium, University of Toronto, February 3-4, 2012. http://www.academia.edu/1225759/Death_of_a_Banker_Dimitrios_ Skanavis_d._1788 Erişim: 16 Eylül 2015.

Neumann, Christoph K.: "Birey olmanın alameti olarak tüketim kalıpları: 18. yüzyıl Osmanlı meta evreninden örnek vakalar”, Tarih ve Toplum Yeni Yaklaşımlar, 8 (İstanbul 2009), s. 7-47.

Öğün, Tuncay: "Osmanlı Devleti'nde Müsadere Uygulamaları”, Osmanl, c. 6: Teşkilat, ed. Güler Eren, Ankara: Yeni Türkiye Yayınları 1999, s. 371-383.

Özcan, Abdülkadir: "Beşir Ağa, Moralı", TDV İslâm Ansiklopedisi, V (İstanbul 1992), s. 555-556.

Özel, Oktay: Dün Sancısı: Türkiye’de Geçmiş Algısı ve Akademik Tarihçilik, İstanbul: Tarih Vakfi Yurt Yay. 2012.

Özgen, Elif: Grand Vizier Koca Sinan Paşa and Factional Politicis in the Court of Murad III, (Yayımlanmamış Yüksek Lisans Tezi) İstanbul: İstanbul Bilgi Üniversitesi, 2010.

Peksevgen, Şefik: Secrecy, Information Control and Power Building in the Ottoman Empire, 1566-1603, (Yayımlanmamış Doktora Tezi) Montreal 2004.

Philliou, Christine M.: Biography of an Empire: Governing Ottomans in an Age of Revolution, London: University of California Press 2011.

Riedler, Florian: Osmanlı Imparatorluğu'nda Muhalefet ve Meşruiyet: Siyasi Kültür ve Komplolar, çev. Azize F. Çakır, İstanbul: Picus Yay. 2012.

Sahillioğlu, Halil: "Askeri”, TDV İslâm Ansiklopedisi, III (İstanbul 1991), s. 488-489.

Salzmann, Ariel: Modern Devleti Yeniden Düşünmek: Osmanlı Ancien Regime’i, çev. Ayşe Özdemir, İstanbul: İletişim Yay. 2011.

Sarıcaoğlu, Fikret: "Hasan Paşa, Seyyid”, TDV İslâm Ansiklopedisi, XVI (İstanbul 1997), s. 339-340.

: Kendi Kaleminden Bir Padişahın Portresi: Sultan I. Abdülhamid (1774-1789), İstanbul: TATAV Yay. 2001.

Sevgen, Necibe: "Nasıl Sömürüldük?: Sarraflar", Belgelerle Türk Tarihi Dergisi, 13 (1968), s. 46-59; 14 (1968), s. 66-68; 15 (1968), s. 59-65; 16 (1969), s. 54-61; 17 (1969), 
s. 62-66; 18 (1969), s. 76-78; 19 (1969), s. 66-67; 20 (1969), s. 69-70; 21 (1969),

s. 67-69; 22 (1969), s. 66-71; 23 (1969), s. 74-75; 24 (1969), s. 54-60; 25 (1969),

s. 73-74.

Süleyman İzzi, Tarih-i $\dot{I} z z i$, Dersaadet: 1199.

Şahiner, Araks: The Sarrafs of İstanbul: Financiers of the Empire, (Yayımlanmamış Yüksek Lisans Tezi) İstanbul: Boğaziçi Üniversitesi Sosyal Bilimler Enstitüsü, 1995.

Şem'dânî-zâde Fındıklılı Süleyman Efendi: Mür'i't-Tevârih, c. II/A, haz. Münir Aktepe, İstanbul: İstanbul Üniversitesi Edebiyat Fakültesi Yay. 1976.

Târîh-i Râşid ve Zeyli, c. I, haz. Abdülkadir Özcan vd., İstanbul: Klasik Yay. 2013.

Taş, Hülya: “Osmanlıda "Şikayet Hakkı”nın Kullanımı Üzerine Düşünceler”, Memleket Siyaset Yönetim, 2/3 (Ankara 2007), s. 187-188.

Taylesanizâde Hâfız Abdullah Efendi Tarihi: İstanbul'un Uzun Dört Yılı (1785-1789), haz. Feridun M. Emecen, İstanbul: TATAV Yay. 2003.

Telci, Cahit: "Osmanlı Devletinde 18. Yüzyılda Muhallefat ve Müsadere Süreci”, Tarih İncelemeleri Dergisi, XXII/2 (İzmir 2007), s. 145-166.

Tuğlacı, Pars: Tarih Boyunca Batı Ermenileri, c. I, İstanbul: Pars Yayın Ticaret 2004.

Uluçay, M. Çağatay: Padişahların Kadınları ve Kızları, Ankara: TTK 1985.

Uzunçarşılı, İsmail Hakkı: Osmanlı Devleti Teşkilatından Kapukulu Ocakları, c. I, Ankara: TTK 1984.

: Osmanlı Devletinin Merkez ve Bahriye Teşkilatı, Ankara: TTK 1988.

: Osmanl Tarihi, c. 4/1, Ankara: TTK 1995.

: Osmanl Tarihi, c. 4/2, Ankara: TTK 2003.

: "Halil Hamid Paşa”, Türkiyat Mecmuası, 5 (İstanbul 1936), s. 213-269.

....... : "Cezayirli Gazi Hasan Paşa'ya Dair”, Türkiyat Mecmuası, 7 (İstanbul 1942), s. 2-44.

Ülker, Necmi: "XVIII. Yüzyılda Mısır ve Cezayirli Hasan Paşa’nın Mısır Seferi”, Tarih İncelemeleri Dergisi, 9/1 (İzmir 1994), s. 1-30.

van den Boogert, Maurits H.: Kapitülasyonlar ve Osmanlı Hukuk Sistemi: 18. yüzyılda kadılar, konsoloslar ve beratlılar, çev. Ali Coşkun Tuncer, İstanbul: Türkiye İş Bankası Yay. 2014. 
